\title{
How the Rockefeller Laws Hit the Streets: Drug Policing and the Politics of State Competence in New York City, 1973-1989
}

\author{
Mason B. Williams (it)
}

Recent studies have shown that the punitive drug laws enacted in the mid-1970s led to a sharp increase in incarceration only in the mid-1980s, when city police departments started policing street-level drug markets much more intensively. The case study of New York City in the wake of the Rockefeller Drug Laws of 1973 presents an explanation. Only when new policing ideas, popular dissatisfaction with street crime, and the revival of the city's fiscal capacity coalesced as part of a larger project to rebuild urban governance in the aftermath of the fiscal crisis of the 1970s did New York turn toward street-level drug enforcement. An examination of the political history of street-level drug enforcement offers a better understanding of the history of New York's war on drugs, as well as a new chronology of the political dynamics of state rebuilding in the 1980s.

In May 1973, "with panoply and fanfare and some caustic words for his critics," New York State Governor Nelson Rockefeller signed into law the nation's most punitive drug laws. ${ }^{1}$ Intended to remove ostensibly incorrigible "pushers" from the state's communities, the legislation established severe penalties for the sale and possession of narcotics and other drugs, imposing mandatory life terms with the chance of parole; a concurrent measure set new mandatory minimums for second felony offenders. ${ }^{2}$ Critics and impartial analysts alike predicted that New York State's prisons would overflow. New York City Mayor John Lindsay, the Rockefeller laws' most prominent opponent, predicted that the state's prison population would grow by at least 50 percent in the first year alone. ${ }^{3}$ Prosecutors and corrections officials girded themselves for a crush of new felony cases and prison commitments. ${ }^{4}$

Yet in the immediate aftermath of the Rockefeller laws' enactment, drug-related incarceration did not grow much at all in New York State. For several years, drug felony sentences as a share of total state prison commitments remained roughly what they had been before the

I would like to thank Elizabeth Blackmar, Brent Cebul, Ruth Wilson Gilmore, Elizabeth Hinton, Julilly Kohler-Hausmann, Suleiman Osman, Kim Phillips-Fein, Alexis Schaitkin, and the anonymous reviewers for Modern American History for their comments on earlier drafts of this article. My thanks also to Sarah Phillips and the assistants at $M A H$ for their editorial guidance; to Eli Miller for research assistance; to Brian Balogh, Lily Geismer, Brian Goldstein, Matthew Lassiter, and the Political Science department at Williams College for advice and support on this project; and to audiences at the Harvard Kennedy School's Seminar on History and Policy, the Policy History Conference, and the 2015 "Violence \& the City" conference at the City University of New York for their generous feedback.

${ }^{1}$ William E. Farrell, “Governor Signs His Drug Bills and Assails His Critics Again,” New York Times, May 9, 1973, 1 [hereafter, NYT].

${ }^{2}$ On the Rockefeller Laws' legislative history, see Julilly Kohler-Hausmann, Getting Tough: Welfare and Imprisonment in 1970s America (Princeton, NJ, 2017), 90-104.

${ }^{3}$ Max H. Seigel, “Lindsay Assails Governor's Plan to Combat Drugs,” NYT, Jan. 10, $1973,1$.

${ }^{4}$ For instance, see James M. Markram, "The Fight on Narcotics: End of Plea Bargaining Is Regarded as Prelude to Overburdened Courts,” NYT, Jan. 9, 1973, 79; “Bar Unit Warns on Drug Proposal,” NYT, Jan. 25, 1973, 27.

(c) The Author(s), 2021. Published by Cambridge University Press 
Rockefeller laws. ${ }^{5}$ Then, after 1975 , the share of New York's prison population incarcerated for drug offenses actually declined sharply. As late as 1983, a full decade after Rockefeller had signed the most punitive drug legislation in American history, the percentage of New York State prison inmates incarcerated for drug violations was lower than it had been in the early 1960s, during the heyday of what historians have termed the treatment era. ${ }^{6}$

As David Weiman and Christopher Weiss have shown, the punitive turn of the late 1960s and early 1970s yielded a major increase in drug-related incarceration in New York only in the mid-1980s, as a consequence of sharp changes in policing practices in New York City, where nearly 80 percent of felony drug arrests during this period occurred. After policing street-level drug markets sporadically through much of the 1970s, the New York Police Department (NYPD) launched a concerted campaign against them; the resulting felony arrests sent the proportion of New York State inmates incarcerated for drug offenses soaring-from under 10 percent at the start of the 1980 s to nearly 35 percent at the end. ${ }^{7}$ This pattern was hardly unique to New York-in Chicago, for instance, drug arrests as a share of all arrests fell steadily from 1976 to 1982 before rising sharply in the mid-1980s. ${ }^{8}$ To note, this is not to diminish the immediate political impact of the punitive laws of the 1970s, much less their repercussions for the people charged under them. But it is to note that the impact of the laws emerged most heavily only once the NYPD and other police departments turned them into an engine of mass incarceration. And it is to suggest that the rich literature on this crucial episode in America's war on drugs still lacks a critical chapter. ${ }^{9}$

The Rockefeller laws did not immediately produce much higher rates of incarceration, as Weiman and Weiss detail, because until the early 1980s, the New York Police Department consciously chose not to enforce them at the street level, effectively defying the intent of state law and the national war on drugs. To understand why the Rockefeller laws finally did contribute to soaring rates of incarceration, we need to examine the local politics of enforcement with respect to informal economies - the question of why politicians and state officials tolerated violations of the law at some moments (and in some spaces) but not at others. ${ }^{10}$ Specifically, we need to

\footnotetext{
5“[D]rug law sentences under the 1973 law did not constitute a significantly larger fraction of annual new commitments to State prisons than in the past ... offenders in prison as a result of drug felonies accounted for only $11 \%$ of the June 1973 population and still accounted for only 11\% of the December 1975 population," quoted in National Institute of Law Enforcement and Criminal Justice, Law Enforcement Assistance Administration, United States Department of Justice, The Nation's Toughest Drug Law: Evaluating the New York Experience, Final Report of the Joint Committee on New York Drug Law Evaluation (New York, 1977), 12.

${ }^{6}$ The overall number of people incarcerated for drug offenses remained roughly unchanged. On the "treatment era," see Jessica Neptune, "The Making of the Carceral State: Street Crime, The War on Drugs, and Punitive Politics in New York, 1951-1973" (Ph.D. diss., University of Chicago, 2012).

${ }^{7}$ David F. Weiman and Christopher Weiss, "The Origins of Mass Incarceration in New York State: The Rockefeller Drug Laws and the Local War on Drugs," in Do Prisons Make Us Safer? The Benefits and Costs of the Prison Boom, eds. Steven Raphael and Michael A. Stoll (New York, 2009), 73-118, here 88, 97.

${ }^{8}$ Peter C. Pihos, "Policing, Race, and Politics in Chicago" (Ph.D. diss., University of Pennsylvania, 2015), 445.

${ }^{9}$ See Kohler-Hausmann, Getting Tough, 114-6. Other important works on the Rockefeller laws include Julilly Kohler-Hausmann, “The Attila the Hun Law': New York's Rockefeller Drug Laws and the Making of the Punitive State," Journal of Social History 44, no. 1 (Fall 2010): 71-95; Neptune, "The Making of the Carceral State"; Jessica Neptune, "Harshest in the Nation: The Rockefeller Drug Laws and the Widening Embrace of Punitive Politics," Social History of Alcohol and Drugs 26, no. 2 (Summer 2012): 170-91; Stuart Schrader, "A Carceral Empire: Placing the Political History of U.S. Prisons and Policing in the World," in Shaped by the State: Toward a New Political History of the Twentieth Century, eds. Brent Cebul, Lily Geismer, and Mason B. Williams (Chicago, 2019), 289-316; and Michael Javen Fortner, Black Silent Majority: The Rockefeller Laws and the Politics of Punishment (Cambridge, MA, 2015). For a critical assessment of Fortner's argument, see Donna Murch, "Who's to Blame for Mass Incarceration?," Boston Review, Oct. 16, 2015, http://bostonreview. net/books-ideas/donna-murch-michael-javen-fortner-black-silent-majority (accessed Aug. 5, 2019).

${ }^{10}$ On forbearance as an arena of urban politics, see Alisha Holland, "The Distributive Politics of Enforcement," American Journal of Political Science 59, no. 2 (Apr. 2015): 357-71. A growing literature examines informal economies in late-twentieth-century American cities (building on work on the early twentieth century). For instance,
} 
determine why the NYPD started intensively policing street-level drug markets in the mid-1980s after consciously choosing not to do so for more than a decade.

This question presents a puzzle because none of the most likely explanations, by themselves, can make sense of precisely when New York turned toward street-level enforcement. Popular dissatisfaction with street crime played an important role in the NYPD's decision to start policing street-level drug markets. But crime rates, though still high by historical standards, had actually been falling for several years when the NYPD launched its first major enforcement initiative. The federal War on Drugs provided resources and incentivized local officials to pursue local drug wars through grants and (later) changes in civil forfeiture laws. But such inducements had failed to sway the NYPD from its nonenforcement policy for over a decade, and when local officials did launch local campaigns in the mid-1980s, they envisioned them as a response to federal inaction. The rise of "proactive," "order maintenance," and "problem-oriented" policing paradigms in the mid-to-late 1970s (recast as "broken windows" policing in the early 1980s) provided an intellectual rationale for street-level enforcement. ${ }^{11}$ Yet NYPD officials did not envision street-level drug policing as part of a broader strategic crime-control plan; they launched their campaigns with little advance strategic planning, generally marshalling academic arguments after the fact. Edward Koch's ascent to the mayoralty in 1978 brought to power a conservative, tough-on-crime coalition. ${ }^{12}$ But Koch placed little priority on street-level policing in his first term, and by the mid-1980s his position on drug policing differed little from his progressive challengers-who often critiqued him for not doing more. New York's economic and fiscal recovery in the mid-1980s removed a key constraint that had prevented the NYPD from policing more actively in the 1970s, but it hardly contradicted the other considerations that had guided the NYPD's policy of nonenforcement, and of course there existed many other competing claims on these newly available resources. The proliferation of crack markets in the city helped to lock in the NYPD's turn toward street-level enforcement. But crack became a major concern to the NYPD only in the spring of 1986, more than two years after the department's turn toward street-level drug policing. Nor was the turn to street-level drug policing as a whole a straightforward effort at gentrification, or a simple response to the political demands of gentrifiers-though its logic as a governing strategy meant that it became entangled with gentrification in specific places, particularly the East Village and the Lower East Side.

The developing literature on urban policing in the 1980s suggests that, while local political actors everywhere were responding to broad structural contexts of disinvestment, concentrated poverty, and dwindling federal support, their choices were also driven by distinctive local

see, Matthew Vaz, “'We Intend to Run It': Racial Politics, Illegal Gambling, and the Rise of Government Lotteries in the United States, 1960-1985," Journal of American History 101, no. 1 (Jun. 2014): 71-96; Matthew Vaz, Running the Numbers: Race, Police, and the History of Urban Gambling (Chicago, 2020); Jess Bird, "Fire in the Bronx: Austerity, Quality of Life, and Nightlife Regulation in New York City Post-1975," Journal of Urban History 46, no. 4 (Jul. 2020): 836-53; and Pedro A. Regalado, "The Washington Heights Uprising of 1992: Dominican Belonging and Urban Policing in New York City," Journal of Urban History 45, no. 5 (Sep. 2019): 961-86. The most important work on the politics of forbearance/enforcement in 1980s New York is Alex S. Vitale, City of Disorder: How the Quality of Life Campaign Transformed New York Politics (New York, 2008). Vitale's treatment of the rise of punitive approaches to homelessness-the basis of a broader turn toward a "quality-of-life" policing strategy - finds that neoconservative social policies gained traction partly as a consequence of community backlash against forms of disorder that occurred as a result of neoliberal developmental policies-a framework which, in its broad strokes, aligns with this treatment of street-level drug policing.

${ }^{11}$ On the NYPD's efforts to institute order-maintenance policing, see Themis Chronopoulos, "The Making of the Orderly City: New York since the 1980s," Journal of Urban History 46, no. 5 (Sep. 2020): 1085-1116. Danielle Wiggins, "'Order as Well as Decency': The Development of Order Maintenance Policing in Black Atlanta," Journal of Urban History 46, no. 4 (Jul. 2020): 711-27 anticipates this essay's emphasis on the sources of political support for order-maintenance policing.

${ }^{12}$ See Weiman and Weiss, "The Origins of Mass Incarceration in New York State," the primary extended analysis of the politics of drug policing in 1980s New York. 
political and institutional dynamics. In Chicago and Los Angeles, as in New York, street-level drug arrests rose sharply in the early-to-mid-1980s, in the years before the proliferation of crack cocaine. ${ }^{13}$ Chicago's turn toward street-level enforcement was shaped by the progressive mayor Harold Washington's battles with the city council and the Chicago Police Department (CPD) and by rising attention to youth violence, which many politicians and the press associated with gangs; in that context, Washington and the CPD began to "target drug use and sales as a proxy for gang activity." 14 In Los Angeles, too, the LAPD expanded the local war on drugs as part of a mid-1980s effort to attack street gangs; local factors such as the arrival of the 1984 Summer Olympics and Mayor Tom Bradley's gubernatorial ambitions also contributed. ${ }^{15}$

New York City's shift toward street-level drug policing occurred only when new policing ideas, popular dissatisfaction with street crime, and the revival of the city's fiscal capacity coalesced as part of a larger project to rebuild urban governance in the aftermath of the fiscal crisis of the 1970s. New York's local war on drugs unfolded in the context of the political imperatives of the crisis of governance that had wracked New York and other American cities since the mid-1970s - an era of deindustrialization, insolvency, and collapsing city services. By the mid-1980s, the worst of that crisis had passed, but it left two important political legacies that formed the immediate context for New York's turn toward street-level drug policing. First, the failure of public services in the 1970s had called the state's competence and authority into doubt, leaving it prone to challenges by private alternatives. ${ }^{16}$ Second, the economic crisis of the 1970s had redoubled policy makers' efforts to attract and maintain investment and affluent residents-a major theme in city politics since at least the 1960s, and one that now moved to the very center of city governance.

New York turned to street-level drug policing when it did because it offered a way to address these particular dilemmas of urban governance. First, it allowed the government to perform concern and capability at a time when the NYPD lacked an effective strategy for reducing serious crime: the displacement of street-level markets was something the city could do and also something it could communicate to citizens through the discourses of statistics and dramatic visuals. Second, street-level drug policing promised to aid the city's effort to reclaim urban spaces for "legitimate" uses-an important component, city policy makers believed, of a broader project to encourage capital investment and the presence of middle-class residents. In the end, New York's turn toward street-level drug policing was an effort to reassert state authority-an attempt to demonstrate, in the face of mounting evidence to the contrary, that public authorities were not altogether impotent to combat urban disorder and that cities could be, at least to a degree, masters of their own fate.

The Rockefeller laws and street-level drug policing clearly shaped the lives of tens of thousands of Americans, and are important in their own right. But these topics also illuminate broader questions of interest to historians-particularly historians of the carceral state, recent

\footnotetext{
${ }^{13}$ Pihos, "Policing, Race, and Politics in Chicago," 445; Max Felker-Kantor, Policing Los Angeles: Race, Resistance, and the Rise of the LAPD (Chapel Hill, NC, 2018), 194.

${ }^{14}$ Pihos, "Policing, Race, and Politics in Chicago," 383-418, here 394.

${ }^{15}$ Donna Murch, "Crack in Los Angeles: Crisis, Militarization, and Black Response to the Late Twentieth-Century War on Drugs," Journal of American History 102, no. 1 (Jun. 2015): 162-73; Felker-Kantor, Policing Los Angeles, 190-216.

${ }^{16}$ On the growth of the private security industry and the proliferation of the resident patrols in the 1970s and early 1980s, see Benjamin Holtzman, "Expanding the Thin Blue Line: Resident Patrols and Private Security in Late Twentieth-Century New York," Modern American History 3, no. 1 (Mar. 2020): 47-67; Joe Merton, "John Lindsay, the Association for a Better New York, and the Privatization of New York City, 1969-1973," Journal of Urban History 45, no. 3 (May 2019), 557-77; and Merton, "Civilian Anticrime Patrols in 1970s New York: Crime, Self-Help and Citizenship in the Neoliberal City," Gotham Center for New York City History Blog, May 19, 2020, https://www.gothamcenter.org/blog/civilian-anticrime-patrols-in-1970s-new-york (accessed Sep. 15, 2020).
} 
American political history, and the history of American cities. This local story puts the relations between-and sometimes the competing interests of-different political actors at the center of the war on drugs. ${ }^{17}$ As political scientists and legal scholars have long emphasized, disjunctures between what the law promises (or commands) and what happens on the ground constitute an integral feature of American governance-particularly in policy areas such as criminal justice, where governance involves actors at multiple levels of government, each with different institutional interests and political constituencies. ${ }^{18}$ Historians of the carceral state have been unusually attuned to the fact that local implementation does not follow automatically from the formulation of policy at the state or national level. ${ }^{19}$ Yet we still know much more about the

\footnotetext{
${ }^{17}$ See Elizabeth Hinton, From the War on Poverty to the War on Crime: The Making of Mass Incarceration in America (Cambridge, MA, 2016), 9-10. The literature on the carceral state in the late twentieth century is vast. An excellent review of the earliest work is Heather Ann Thompson, "Why Mass Incarceration Matters: Rethinking Crisis, Decline, and Transformation in Postwar American History," Journal of American History 97, no. 3 (Dec. 2010): 703-34. In addition to works cited above, see Michael W. Flamm, Law and Order: Street Crime, Civil Unrest, and the Crisis of Liberalism in the 1960s (New York, 2005); Marie Gottschalk, The Prison and the Gallows: The Politics of Mass Incarceration in America (Princeton, NJ, 2006); Vesla M. Weaver, "Frontlash: Race and the Development of Punitive Crime Policy," Studies in American Political Development 21, no. 2 (Fall 2007): 230-65; Ruth Wilson Gilmore, Golden Gulag: Prisons, Surplus, Crisis, and Opposition in Globalizing California (Berkeley, CA, 2007); Jonathan Simon, Governing through Crime: How the War on Crime Transformed American Democracy and Created a Culture of Fear (New York, 2007); Loïc Wacquant, Punishing the Poor: The Neoliberal Government of Social Insecurity (Durham, NC, 2009); Michelle Alexander, The New Jim Crow: Mass Incarceration in the Age of Colorblindness (New York, 2010); Kathleen J. Frydl, The Drug Wars in America, 1940-1973 (New York, 2013); Naomi Murakawa, The First Civil Right: How Liberals Built Prison America (Princeton, NJ, 2014); Kelly Lytle Hernández, Khalil Gibran Muhammad, and Heather Ann Thompson, "Constructing the Carceral State," Journal of American History 102, no. 1 (Jun. 2015): 18-24; and the essays contained in this special issue, "Historians and the Carceral State"; Heather Ann Thompson, Blood in the Water: The Attica Prison Uprising of 1971 and Its Legacy (New York, 2016); and Melanie Newport, Community of the Condemned: Chicago and the Transformation of American Jails (Philadelphia, forthcoming). For a more complete bibliography, see https://www.aaihs.org/prison-abolition-syllabus/ (accessed July 30, 2019).

A growing literature focuses specifically on policing. See Christina B. Hanhardt, Safe Space: Gay Neighborhood History and the Politics of Violence (Durham, NC, 2013); Christopher Lowen Agee, The Streets of San Francisco: Policing and the Creation of a Cosmopolitan Liberal Politics, 1950-1972 (Chicago, 2014); Pihos, "Policing, Race, and Politics in Chicago"; Jordan T. Camp and Christina Heatherton, eds., Policing the Planet: Why the Policing Crisis Led to Black Lives Matter (New York, 2016); Alex Elkins, "Battle of the Corner: Urban Policing and Rioting in the United States, 1943-1971" (Ph.D. diss., Temple University, 2017); Felker-Kantor, Policing Los Angeles; Clarence Taylor, Fight the Power: African Americans and the Long History of Police Brutality in New York City (New York, 2018); Simon Balto, Occupied Territory: Policing Black Chicago from Red Summer to Black Power (Chapel Hill, NC, 2019); Anne Gray Fischer, "Land of the White Hunter': Legal Liberalism and the Racial Politics of Morals Enforcement in Midcentury Los Angeles," Journal of American History 105, no. 4 (Mar. 2019), 868-84; Stuart Schrader, Badges without Borders: How Global Counterinsurgency Transformed American Policing (Berkeley, CA, 2019); Schrader, "A Carceral Empire"; Carl Suddler, Presumed Criminal: Black Youth and the Justice System in Postwar New York (New York, 2019); Wiggins, "'Order as well as Decency"; and the essays in Christopher Lowen Agee and Themis Chronopoulos, eds., "Special Section: Urban America and the Police since World War II," Journal of Urban History 46, no. 5 (Sep. 2020): 951-1116.

${ }^{18}$ This disjuncture has been a major theme in legal history and legal-studies analysis over the past several decades. Studies dealing specifically with policing include Michael Lipsky, Street-Level Bureaucracy: Dilemmas of the Individual in Public Services, 2nd ed. (New York, 2010); and Michael K. Brown, Working the Street: Police Discretion and the Dilemmas of Reform (New York, 1988). For an overview of recent historical work, see Brent Cebul, Karen Tani, and Mason B. Williams, "Clio and the Compound Republic," Publius: The Journal of Federalism 46, no. 2 (Spring 2017): 235-59.

${ }^{19}$ Hinton in particular highlights the processes by which federal policy makers "imposed" the war on drugs as a priority for local officials, stressing the role of federal grants and civil forfeiture laws. See Hinton, "From the War on Crime to the War on Drugs," in From the War on Poverty to the War on Crime, 307-32, here 318. Two pathbreaking studies of the war on drugs at the state and city levels, respectively, are Matthew D. Lassiter, "Impossible Criminals: The Suburban Imperatives of America's War on Drugs," Journal of American History 102, no. 1 (Jun. 2015): 126-40; and Murch, "Crack in Los Angeles," 162-73. This essay examines policy making at the mayoral and departmental levels, which is amply documented in mayoral records. Constraints on access to the NYPD's
} 
development of national and state law, policy, and programs than we do about how those policies were implemented and administered on the ground.

In the case of drug policing in the wake of the Rockefeller laws, foregrounding the politics of enforcement calls attention to political influences that shaped street-level policing in the mid-1980s, not the least of which was the rise of real estate capitalism and the governmental imperatives bound up with it. ${ }^{20}$ This helps us take a broader view of the role of federal policy in shaping the urban war on drugs. Though Ronald Reagan appears only in passing, federal policy is very much central to the history recounted here-but its primary impact was indirect. New York's local war on drugs unfolded within the context of a broad, federally subsidized racial and economic segmentation of metropolitan America that dated back decades, and which entered a new phase with Reagan's New Federalism and the deregulation of the finance sector. ${ }^{21}$ By concentrating poverty in segregated and disinvested communities of color, these policies had multiplied the challenges of urban governance; by tying the fiscal capacity of local states to the rising finance, insurance, and real estate industries, they had encouraged city officials to think of city politics as a competition for investment and affluent residents and to forge a link between order, value, and state competence. These conditions, more than direct financial incentives, helped the federal government to secure local buy-in for a war on drugs that many local officials-including relatively conservative ones like New York City Mayor Edward Koch-had viewed with skepticism.

By highlighting the roles that political actors from across the ideological spectrum played in an undertaking often associated with Reagan, the history of New York City's war on drugs also challenges scholars to reexamine the relationship between ideology and partisanship, on the one hand, and the structural and institutional features that shape policy making, on the other. ${ }^{22}$ One of the major themes of the carceral state literature in recent years has been

records make it considerably more challenging to assess how departmental policy was implemented at the street level. This essay compensates by using first-hand observations by contemporary researchers, as well as reporting by citywide, neighborhood, and Spanish language newspapers to shed light on policing at the street level. Still, a lack of access to official sources imposes real limits on the analysis of policy implementation.

${ }^{20}$ For an account of the relation between policing and property in an earlier period of American urban history, see N. D. B. Connolly, “Games of Chance: Jim Crow's Entrepreneurs Bet on 'Negro' Law and Order," in What's Good for Business: Business and American Politics since World War II, eds. Kim Phillips-Fein and Julian E. Zelizer, (New York, 2012), 140-56. Wiggins, “'Order as Well as Decency” offers a pathbreaking examination of the same issues in the 1970s.

${ }^{21}$ Starting points in the enormous literature on race and postwar metropolitan development include Kenneth T. Jackson, Crabgrass Frontier: The Suburbanization of the United States (New York, 1985), ch. 11; David M. P. Freund, Colored Property: State Policy and White Racial Politics in Suburban America (Chicago, 2007); Colin Gordon, Mapping Decline: St. Louis and the Fate of the American City (Philadelphia, 2008); Thomas J. Sugrue, Sweet Land of Liberty: The Forgotten Struggle for Civil Rights in the North (New York, 2008), ch. 7; Beryl Satter, Family Properties: Race, Real Estate, and the Exploitation of Black Urban America (New York, 2009); and N. D. B. Connolly, A World More Concrete: Real Estate and the Remaking of Jim Crow South Florida (Chicago, 2014). On the deregulation of finance, see Greta R. Krippner, Capitalizing on Crisis: The Political Origins of the Rise of Finance (Cambridge, MA, 2011). For an overview of federal urban policy and intergovernmental transfers, see Peter Dreier, John H. Mollenkopf, and Todd Swanstrom, Place Matters: Metropolitics for the Twenty-First Century, 3rd ed. (Lawrence, KS, 2014), ch. 5.

${ }^{22}$ Matthew D. Lassiter, "Political History Beyond the Red-Blue Divide," Journal of American History 98, no. 3 (Dec. 2011): 760-4; Cebul, Geismer, and Williams, Shaped by the State; Bruce J. Schulman, "Neo-Consensus History for the Age of Polarization," Reviews in American History 47, no. 3 (Sep. 2019): 479-99. Important works on national politics in the 1980s include Gil Troy, Morning in America: How Ronald Reagan Invented the 1980s (Princeton, NJ, 2005); Sean Wilentz, The Age of Reagan: A History, 1974-2008 (New York, 2008); Doug Rossinow, The Reagan Era: A History of the 1980s (New York, 2015); and Kevin M. Kruse and Julian E. Zelizer, Fault Lines: A History of the United States Since 1974 (New York, 2019). An especially rich literature examines the politics of race, class, and gender. See, among others, Alice O'Connor, Poverty Knowledge: Social Science, Social Policy, and the Poor in Twentieth-Century U.S. History (Princeton, NJ, 2001); Nancy MacLean, Freedom Is Not Enough: The Opening of the American Workplace (Cambridge, MA, 2008), chs. 8 and 9; Marisa 
the central role of liberals in the war on crime and mass incarceration. ${ }^{23}$ By stressing the bipartisan nature of America's insistence on "governing through crime," scholars have questioned a liberalism-vs.-conservatism narrative of post-New Deal American political history. Rather than seeing conservatives as "tough on crime" and Democrats as ready to go along for the sake of electoral success, these scholars view politicians from both parties as searching for strategies that would allow them to govern without substantial economic redistribution or challenges to the racial order.

Not only were key episodes in the war on drugs bipartisan; in the case of 1980s New York, ideological-political positions themselves could sometimes be less significant than the broad dilemmas of governance with which policy makers of many ideological stripes found themselves confronted. Perhaps it is not surprising to see Ed Koch, the self-styled "liberal with sanity" whose coalition responded to his racially coded "get tough" rhetoric, leading the push for a local war on drugs. It might be more surprising to see Democrats well to Koch's left challenging him over who could be tougher on street-level drug markets. The key to this puzzle is recognizing that these liberal-progressive Democrats, like the "New Democrat" Koch, embraced street-level drug policing less out of ideological conviction or a desire to claim the political center than because it offered a strategy that promised to address dilemmas of municipal governance in the era of Reaganism. By cutting across the usual ideological and partisan categories, this history helps us to see categories such as the New Democrats as politicalnarrative constructs that existed in uneasy tension with patterns of governance sometimes better understood in nonpartisan terms. ${ }^{24}$

Finally, the history of street-level drug policing in New York casts new light on the construction of the neoliberal state-the turn toward deregulation, privatization of formerly public functions, de-socialization of goods and services, municipal austerity, and other related shifts in governance characteristic of American cities in the last quarter of the twentieth century. ${ }^{25}$

Chappell, The War on Welfare: Family, Poverty, and Politics in Modern America (Philadelphia, 2010); Robert O. Self, All in the Family: The Realignment of American Democracy since the 1960s (New York, 2012); Michael B. Katz, The Undeserving Poor: America's Enduring Confrontation with Poverty, 2nd ed. (New York, 2013); Tamar W. Carroll, Mobilizing New York: AIDS, Antipoverty, and Feminist Activism (Chapel Hill, NC, 2015); and Brian D. Goldstein, The Roots of Urban Renaissance: Gentrification and the Struggle Over Harlem (Cambridge, MA, 2017).

Much recent historical scholarship on American politics in the 1980s has documented the ways in which opponents blocked, constrained, and frustrated the conservatives who had claimed power at the national level. See Meg Jacobs and Julian E. Zelizer, Conservatives in Power: The Reagan Years, 1981-1989 (New York, 2010); Bradford Martin, The Other Eighties: A Secret History of America in the Age of Reagan (New York, 2011); Michael Stewart Foley, The Forgotten Heyday of American Activism in the 1970s and 1980s (New York, 2013); Lily Geismer, Don't Blame Us: Suburban Liberals and the Transformation of the Democratic Party (Princeton, NJ, 2015); and Jefferson Decker, The Other Rights Revolution: Conservative Lawyers and the Remaking of American Government (New York, 2016). This essay builds on that literature by emphasizing the contingent nature of initiatives like the war on drugs. But it also highlights the role non-ideological and liberal political forces played in undertakings often associated with Reagan.

${ }^{23}$ For instance, see Murakawa, The First Civil Right; Agee, Streets of San Francisco; Hinton, From the War on Crime to the War on Drugs; and Felker-Kantor, Policing Los Angeles. On New York, see, among others, Joe Merton, "I Don't Believe in a Fun City; I Believe in a Safe City': Fear of Crime and the Crisis of Expertise in New York City," Journal of Policy History 29, no. 1 (Jan. 2017): 112-39; and Suddler, Presumed Criminal.

${ }^{24}$ Brent Cebul, "Supply-Side Liberalism: Fiscal Crisis, Post-Industrial Policy, and the Rise of the New Democrats," Modern American History 2, no. 2 (Jul. 2019): 139-64.

${ }^{25}$ David Harvey, A Brief History of Neoliberalism (New York, 2005), remains an essential starting point. On "neoliberal cities," see Neil Brenner, New State Spaces: Urban Governance and the Rescaling of Statehood (New York, 2004); Jason Hackworth, The Neoliberal City: Governance, Ideology, and Development in American Urbanism (Ithaca, NY, 2007); and Timothy P. R. Weaver, Blazing the Neoliberal Trail: Urban Political Development in the United States and the United Kingdom (Philadelphia, 2016). Important works on New York include William Sites, Remaking New York: Primitive Globalization and the Politics of Urban Community (Minneapolis, MN, 2003); Seth Low and Neil Smith, eds., The Politics of Public Space (New York, 2006); Kim 
While the neoliberalization framework has yielded considerable analytical fruit, the bundling of historical developments under the heading of "neoliberalism" raises some important questions. How do we make sense of the fact that key groups of neoliberals disagreed on fundamental issues? ${ }^{26}$ What if core components of neoliberalization-for instance, business-oriented economic development and market-led privatization-came into conflict? Why did so many progressive politicians, community activists, policy intellectuals, and mezzo-level bureaucrats find themselves entangled in processes of neoliberalization? Why did outer-borough neighborhood groups play an important role in the development of public/private parks governance? Why did progressive teachers help pioneer public school choice? And why did some community activists demand more street-level drug policing? ${ }^{27}$

This essay proposes that we make sense of such puzzles by thinking of neoliberal state building as a process by which a wide variety of actors sought to reconstruct and reenvision the local state's capacity and competence in the wake of the crises of the 1970s. Many of them were committed privatizers, but many were liberals or career policy makers and bureaucrats in search of strategies to recover the local state's capabilities-often in pursuit of traditionally liberal objectives. Mayor Koch and Police Commissioner Benjamin Ward, for example, were contesting assumptions of public ineptitude when they embarked on street-level policing; they aimed to reassert the state's legitimacy in the face of private (in some instances "market-based") alternatives to the provision of public goods. They certainly drew upon neoliberal assumptions-about the importance of property values, the "business climate," and the city's international imagebut they wanted to rebuild the state, not to shrink it. Ward in particular believed he was working in pursuit of a democratic vision of "the public" - what he called a "renaissance of our City's cosmopolitan street life." 28

But as reformers like Koch and Ward tried to rebuild public capacity in the face of privatist, market-based alternatives, they reached accommodations that nevertheless embedded market logic and racial and class privilege in new institutional forms that have proven extraordinarily difficult to dislodge. And so, the history recounted here not only gives us a fuller understanding of how the neoliberal city emerged-and the multiple paths that neoliberalization took-but also helps us to make sense of why these forms have emerged in cities that regard themselves as the most progressive places in America.

It may also be that historians should conceive not only of multiple paths to neoliberalism, but also of different types of neoliberal cities. ${ }^{29} \mathrm{New}$ York is an unusual city, but its recent history is representative of a process that has shaped other affluent, politically progressive citiesLondon and San Francisco are two other leading examples-in which a relatively vital public

Moody, From Welfare State to Real Estate: Regime Change in New York City, 1974 to the Present (New York, 2007); Miriam Greenberg, Branding New York: How a City in Crisis Was Sold to the World (New York, 2008); Julian Brash, Bloomberg's New York: Class and Governance in the Luxury City (Athens, GA, 2011); Jonathan Soffer, Ed Koch and the Rebuilding of New York City (New York, 2010); Amy Starecheski, Ours to Lose: When Squatters Became Homeowners in New York City (Chicago, 2016); and the essays in Themis Chronopoulos and Jonathan Soffer, eds., "Special Section: After the Urban Crisis: New York and the Rise of Inequality," Journal of Urban History 43, no. 6 (Nov. 2017), 855-959.

${ }^{26}$ Lily Geismer, "Agents of Change: Microenterprise, Welfare Reform, the Clintons, and Liberal Forms of Neoliberalism," Journal of American History 107, no. 1 (Jun. 2020): 107-31, calls much needed attention to the "complexity and spectrum of neoliberalism" in the late-twentieth-century United States.

${ }^{27}$ Suleiman Osman, “We're Doing It Ourselves': The Unexpected Origins of New York City's Public-Private Parks During the 1970s Fiscal Crisis," Journal of Planning History 16, no. 2 (May 2017): 162-74; Benjamin Holtzman, The Long Crisis: New York and the Path to Neoliberalism (New York, forthcoming). Several of the works cited in note 26 also highlight this question.

${ }^{28}$ Benjamin Ward to Edward Koch, Apr. 4, 1984, Edward I. Koch Papers, microfilm roll 15, folder 1, box 36, New York Municipal Archives, NY [hereafter NYMA].

${ }^{29}$ Geismer, "Agents of Change," calls much needed attention to the "complexity and spectrum of neoliberalism" in the late-twentieth-century United States. 
realm has produced substantial private value. In New York, unlike in many big cities of the western hemisphere, the affluent and wealthy have not withdrawn from public space and institutions; rather, through a variety of mechanisms - the rise of conservancies and business improvement districts, the workings of the city's public school choice system-they have secured privileged access to them and an outsized role in their management. That New York has long been an unusual American city helps to explain why it became a different type of neoliberal city. Possessed of so staggering a base of taxable capital, New York is the last big city where one would have expected to see the kind of crisis of governmental competence that occurred in the 1970s. In fact, while New York worked to extend the New Deal social state well into the postwar decades, many other cities already faced the concerns over local fiscal competence and economic health that would hit New York so hard after $1969 .{ }^{30}$ In the 1970s those anxieties moved to the center of New York's political life. ${ }^{31}$ But only a few years after they did, the deregulation-driven boom in finance, insurance, and real estate and the expansion of the tourism and creative economies made available the resources for governance projects like those chronicled here. From this conjuncture of anxiety, affluence, and inequality, a different kind of neoliberal city emerged-a luxury city that remains committed to its public institutions, but which has remade those institutions in ways that have rendered them less democratic.

The stability of New York State's drug felony imprisonment rate after 1973 resulted in part from declining rates of indictment and conviction. ${ }^{32}$ Some prosecutors worked to blunt the laws' potential impact: noting that the laws' constraints on plea bargaining applied only after indictment, New York County District Attorney Richard Kuh adopted a policy of allowing small-scale methadone sellers, threatened under the Rockefeller laws with mandatory life sentences, to plead pre-indictment to Class-A misdemeanor charges-an exercise of discretion, Kuh argued, necessary to assure "humane and rational dispositions." 33

But most important was the shoe that did not drop. As one study noted, the Rockefeller laws "implied" an enforcement policy of aggressive street-level policing. ${ }^{34}$ Yet the New York Police Department did the opposite: rather than feeding thousands of users and street-level sellers newly exposed to imprisonment by the Rockefeller laws into the criminal justice system, the NYPD cut back dramatically on the number of drug arrests it made (Table 1).

New York City officials chose consciously to work at cross purposes from Rockefeller and the state legislature. The Rockefeller laws' general unpopularity in the city likely factored into this decision: Mayor John Lindsay was the most outspoken opponent; much of the city's legislative delegation had voted against the measures; and nearly the entire criminal justice establishment opposed them. ${ }^{35}$ But the NYPD's policing approach also reflected the department's own policy learning and institutional prerogatives. In 1969, Lindsay and Police Commissioner Howard Leary had launched an intensive drug policing campaign featuring an emphasis on street-level arrests as well as greater coordination with state and federal

\footnotetext{
${ }^{30}$ Joshua B. Freeman, Working-Class New York: Life and Labor Since World War II (New York, 2000).

${ }^{31}$ Kim Phillips-Fein, Fear City: New York's Fiscal Crisis and the Rise of Austerity Politics (New York, 2017).

${ }^{32}$ National Institute of Law Enforcement and Criminal Justice, Law Enforcement Assistance Administration, United States Department of Justice, The Nation's Toughest Drug Law, 14-6.

${ }^{33}$ M. A. Farber, "Kuh Offers 'Small' Sellers of Methadone Chance to Plead to a Lesser Charge," NYT, June 19, 1974, 94. See Lipsky, Street-Level Bureaucracy, 22.

${ }^{34}$ Joint Committee on New York Drug Law Evaluation, "Enforcement Policies [Paper \#5]," in The Effects of the 1973 Drug Laws on the New York State Courts: A Staff Report of the Drug Law Evaluation Project (New York, 1976), 1, New York City Municipal Library.

${ }^{35}$ Kohler-Hausmann, “The Attila the Hun Law," 81; Fortner, "The Carceral State and the Crucible of Black Politics," 29; Weiman and Weiss, "The Origins of Mass Incarceration in New York State," 89.
} 
Table 1. Felony drug and felony non-drug arrests in New York City, 1970-1975 (New York City Police Department, Statistical Reports, in Joint Committee on New York Drug Law Evaluation, The Nation's Toughest Drug Law, 90)

\begin{tabular}{lcc}
\hline & Felony drug arrests & Felony non-drug arrests \\
\hline 1970 & 26,378 & 57,573 \\
\hline 1971 & 20,473 & 71,248 \\
\hline 1972 & 11,259 & 73,780 \\
\hline 1973 & 7,408 & 68,798 \\
\hline 1974 & 7,439 & 77,545 \\
\hline 1975 & 7,498 & 77,666 \\
\hline
\end{tabular}

authorities - they had, in brief, introduced the policy implied by the Rockefeller laws before their enactment. ${ }^{36}$ Like Rockefeller, Lindsay and the NYPD had been motivated by a belief that narcotics use was driving a (widely perceived) increase in property crime-a major popular concern in communities of all kinds in late 1960 s New York. ${ }^{37}$ As a consequence of this crackdown, in three years between 1967 and 1970, the number of felony drug arrests in the city had risen from 7,199 to $26,378 .^{38}$

But intensive street-level drug policing had not produced the effects Lindsay and the NYPD had hoped. Such a policy was extraordinarily expensive: one study found that nearly a full manweek of effort was required to obtain the evidence necessary to make a street-level sale arrest stand up in court. ${ }^{39}$ Drug cases seemed to soak up valuable criminal justice resources toward no discernible ends. In part because mass drug arrests had overwhelmed the courts, the conviction rates for those arrested on felony drug charges had been a low three-in-ten. ${ }^{40}$ And with no meaningful decline in property crimes, the city seemed to have little to show for this massive investment of public resources.

Two other concerns also increased disillusionment with the street-policing experiment. First, powerful voices within the local criminal justice establishment had begun, with renewed force, to disparage the idea of treating narcotics addiction through the criminal justice system. "As long as drug abusers are treated as outlaws," Lindsay's Criminal Justice Coordinating Council wrote in its 1972 annual report, "any real progress in helping them or even making them harmless will be impossible." 41 Second, a series of corruption scandals (immortalized in the 1973 film Serpico) had exposed the opportunities street-level drug policing afforded unscrupulous officers. The Knapp Commission investigations that grew out of these exposés found that, in addition to the usual shakedowns, officers had sold drugs, helped to finance drug sales, and shielded sellers from arrest in a variety of ways-by revealing the identity of government informants, tipping off dealers about wiretaps and upcoming raids, and even

\footnotetext{
${ }^{36}$ New York Criminal Justice Coordinating Council, Executive Committee, Annual Report of the Criminal Justice Coordinating Council [for] 1971 (New York, 1971), 39.

${ }^{37}$ For instance, see New York Criminal Justice Coordinating Council, Annual Report of the Criminal Justice Coordinating Council [for] 1971, 38-9. On popular dissatisfaction with property crime, see Fortner, "The Carceral State and the Crucible of Black Politics," 21-7, and Murch, "Who's to Blame for Mass Incarceration?"

${ }^{38}$ National Institute of Law Enforcement and Criminal Justice, The Nation's Toughest Drug Law, 90. On streetlevel policing in the 1960s and early 1970s, see Frydl, The Drug Wars, 289-326; Elkins, "Battle of the Corner." On New York in the Lindsay era, see Merton, “I Don't Believe in a Fun City"; and Suddler, Presumed Criminal.

${ }^{39}$ National Institute of Law Enforcement and Criminal Justice, "Enforcement Policies," in The Nation's Toughest Drug Law, 5-6.

${ }^{40}$ Criminal Justice Coordinating Council, Annual Report [for] 1971, 39.

${ }^{41}$ Criminal Justice Coordinating Council, Annual Report [for] 1972, 34.
} 
kidnapping key witnesses. ${ }^{42}$ Such corruption not only indicated the NYPD's limited capacity to police street-level drug markets effectively, but also made drug policing a target for anticorruption reform. The NYPD's subsequent anticorruption reforms thus included a "general prohibition on self-initiated enforcement actions." ${ }^{43}$

And so, beginning in 1972, the city and its police department largely abandoned the street-policing experiment and shifted its attention to mid- and upper-level traffickers. When, in 1973, the enactment of the Rockefeller laws impelled the NYPD to review its policy of street-level non-enforcement, the department consciously chose to continue its own policy in defiance of Rockefeller and the state legislature. ${ }^{44}$ Then, two years later, New York's fiscal crisis hit. With the city on the verge of bankruptcy, the NYPD dismissed some 4,000 police officers and instituted a five-year hiring freeze, which would cost it an additional 8,000 officers by attrition. ${ }^{45}$ Faced with these capacity constraints, the department responded by reallocating nearly all of its resources still committed to street-level drug policing to other functions. ${ }^{46}$

The first major departure from this policy of non-enforcement came, not at the NYPD's initiative, but rather because political leaders, businesses, and media outlets in Harlem pushed Mayor Abraham Beame for more enforcement. Nearly everyone involved in this campaign recognized that street enforcement represented only a palliative and that a real solution to the problems of drug abuse and street crime would begin with a commitment to full employment and other "root causes" measures. ${ }^{47}$ Yet more intensive street policing was something the government appeared relatively able and perhaps willing to provide, and which could be put into operation quickly. In late 1975, the Amsterdam News had declared a community-level "war on crime," calling for greater action against street-level "pushers." ${ }^{48}$ Press coverage, in turn, galvanized the neighborhood's political leaders, most notably Manhattan Borough President Percy Sutton and Congressman Charles Rangel. Sutton, who had recently joined the Auxiliary Police and taken to patrolling northern Manhattan himself, was gearing up to challenge Mayor Beame in the 1977 Democratic primary on an anti-crime platform; Rangel's appointment to the newly formed House Select Committee on Narcotics Abuse and Control in August of 1976 afforded him a platform for calling attention to drug sales in the neighborhood. ${ }^{49}$ In November of 1976, Sutton, Rangel, Beame, and Police Commissioner Michael Codd observed the Eighth Avenue drug markets from a camouflaged police van; this convinced

\footnotetext{
${ }^{42}$ Commission to Investigate Allegations of Police Corruption-Whitman Knapp, Chairman, Commission Report (With Summary and Principal Recommendations, Issued August 3, 1972) (New York, 1972), 91-3. On the Knapp Commission investigations, see Michael F. Armstrong, They Wished They Were Honest: The Knapp Commission and New York City Police Corruption (New York, 2012).

${ }^{43}$ Robert Kane and Michael White, Jammed Up: Bad Cops, Police Misconduct, and the New York City Police Department (New York, 2013), 46.

${ }^{44}$ National Institute of Law Enforcement and Criminal Justice, "Enforcement Policies," in The Nation's Toughest Drug Law, 2.

${ }^{45}$ By the end of the decade, the NYPD had lost 34 percent of its workforce. Kane and White, Jammed Up, 48.

${ }^{46}$ Selwyn Raab, "Police Functions Hard Hit as Layoffs Curb Activity," NYT, July 14, 1975, 1; John Darnton, "New Cuts Felt the Least by Uniformed Services," NYT, Nov. 12, 1975, 27. Phillips-Fein, Fear City, 129-37, documents the police unions' extraordinary effort to resist layoffs.

${ }^{47}$ For instance, an Amsterdam News editorial argued: “All of us know that a police campaign ... is not the answer to the narcotics problem in Harlem or anywhere else. Many fundamental social and economic changes must take place before any lasting alleviation comes about." "Operation Drugs-A Report on Harlem Crime," Amsterdam News, Apr. 9, 1977, B6.

48"Sutton Asked to Lead Crusade; He Accepts: Crime Fighter," Amsterdam News, Dec. 27, 1975, A1; Simon Anekwe, "Harlemites Are Lining Up to Fight Criminals," Amsterdam News, Jan. 10, 1976, A1; H. Carl McCall, "A Hard Line on Crime," Amsterdam News, Jan. 10, 1976, A5.

49"'Sutton Asked to Lead Crusade"; “Percy Sutton Reports' Airs War on Crime," Amsterdam News, Jan. 17, 1976, D2; Lamont Flanagan, "Sutton Is on the Brink of Entering Race for Mayor," Amsterdam News, Dec. 25, 1976, A1; "Rangel to Serve on House Committee on Drug Abuse," Amsterdam News, Aug. 14, 1976, B2; Jack Kelly, "Federal
} 
Beame and Codd to sign off on an effort called Operation Drugs, which sent some 150 uniformed personnel and 75 members of the Narcotics Division into the neighborhood to make street-level arrests-nearly 5,000 in the course of the next four months. ${ }^{50}$

Foisted on the department by Beame, himself acting at the insistence of Harlem's political and media establishment, Operation Drugs never really received buy-in from the NYPD. Police officials speaking anonymously described the operation as "a cynical and perhaps futile product of political pressure." ${ }^{1}$ Whatever skepticism Harlem residents themselves may have felt toward more intensive street-policing proved well founded: the city, unable and unwilling to devote the resources required, engaged not in street-level drug policing, but in simple street sweeps, making Operation Drugs an exercise in harassment for many neighborhood residents. Newspaper reporters who combed the arrest records learned that many of the arrests were for disorderly conduct, not for drug sales or possession, and that they had occurred because "crowds of young men refused to move off street corners when told to do so." 52 Unsurprisingly, prosecutors found that the "number and quality of arrests we are getting from the police is way down." 53 The entire episode seemed only to affirm the position the NYPD had taken in the early 1970s. Only when the department's own political and governing imperatives aligned with those of politicians would street-level drug policing return, and endure.

Even as Operation Drugs wound down to a close, policy intellectuals had begun to revisit the assumptions that had guided the NYPD's retreat from street-level enforcement. In 1977's Buy and Bust, Mark H. Moore of Harvard's Kennedy School recast street-level policing as a way of regulating the narcotics market within the statutory context of prohibition: the police could not eliminate drug sales, he argued, but they could reduce the number of new users by raising the cost of drug transactions. With this goal in mind, Moore urged police departments to engage in buy-and-bust operations to make dealers suspicious of unknown buyers and to eliminate copping areas through active policing-there should be "no area," he wrote, "to which an inexperienced user could come and expect to find heroin." 54

Moore's arguments for more intensive street-level drug policing fit within a broader movement-among police reformers, politicians, and scholars-away from the "reactive," "crime-oriented," cruiser-bound style of the late 1960s and early 1970s and toward "proactive," "order maintenance," and "problem-oriented," street-present strategies. By the time the ordermaintenance approach received its most famous formulation in George Kelling and James Q. Wilson's 1982 essay "Broken Windows," its tenets were already broadly familiar: when New York City Mayor Edward Koch sent Kelling and Wilson's article to Police Commissioner Robert McGuire shortly after its publication, McGuire replied that the essay "broadly confirms this Department's conclusions regarding the efficacy of foot patrols in the City's neighborhoods," detailing the results of an experimental foot patrol program on the Lower East Side. ${ }^{55}$ Unlike later mayors and commissioners, who saw "broken windows"

Committee Holds First Narcotics Hearing," Amsterdam News, Dec. 4, 1976, A7. See also Charles Rangel to Abraham Beame, Nov. 30, 1976, Abraham Beame Papers, microfilm roll 6, folder 4, box 88, NYMA.

${ }^{50}$ Selwyn Raab, "Police Crack Down on Drugs in Harlem," NYT, Dec. 7, 1976, 45; "Operation Drugs-A Report on Harlem Crime.” A strong majority of those arrested during the Operation Drugs campaign-65.4\%—lived outside Harlem.

${ }^{51}$ Raab, "Police Crack Down on Drugs in Harlem," 45.

${ }^{52}$ Mary Breasted, "Police Drive Stalks Heroin Dealers in Harlem,” NYT, Jan. 30, 1977, 1.

${ }^{53}$ Selwyn Raab, "Sales of Illegal Drugs in the City Are Found to Be Commonplace," NYT, Sep. 14, $1979,1$.

${ }^{54}$ Mark H. Moore, Buy and Bust: The Effective Control of an Illicit Market in Heroin (Lexington, MA, 1977), especially ch. 6 , here 264 .

${ }^{55}$ George Kelling and James Q. Wilson, "Broken Windows," The Atlantic, Mar. 1982, 29-38; Koch to McGuire, Mar. 29, 1982; McGuire to Koch, May 12, 1982, Koch Papers, microfilm roll 26, folder 12, box 66, NYMA. 
policing primarily as a crime-control strategy, Koch and McGuire focused on the response it promised to elicit from the public. In his note to McGuire, Koch wrote that Kelling and Wilson's article had "nothing to do with crime but rather with fear"; McGuire did see ordermaintenance policing partly as a crime control tool, but he also emphasized the "favorable public impression" it left, suggesting that it offered a way to "make clear to the public the Department's commitment to restore a feeling of safety and security to all the streets of the City." 56

Yet the lingering effects of the mid-1970s fiscal crisis placed sharp constraints on such initiatives. Mayor Koch, the self-proclaimed "liberal with sanity" who had ascended to the mayoralty in 1978, had won election in part by appeal to "traditionally Democratic white workingclass and middle-class voters ... through his racially laced antiwelfare and law-and-order rhetoric." ${ }^{" 57}$ Yet notwithstanding a few targeted efforts (such as antigraffiti and antirobbery initiatives), he declined during his first term to prioritize policing over public education, saying he would not allocate money to hire more police officers until the city could stop laying off teachers. $^{58}$

This began to change in the fall of 1980, ostensibly in response to public pressures. "In New York City-in every city in the country-personal safety and anger at the escalation of crime is the No. 1 issue," Koch declared. "The people of this city want something done about it [and] I want something done about it...." ${ }^{59}$ His initial program centered on judicial reforms and consisted mostly of recommendations to the state legislature, "designed to insure 'swift and tough' punishment after conviction" (though Koch also proposed pretrial detention). ${ }^{60}$ Then, in the summer of 1981, Koch and the NYPD began to break from the policing strategies of the 1970s. In July, Police Commissioner Robert McGuire announced the formation of a new unit of 100 plainclothes officers to "battle drugs in public places." Officially a response to a surge of complaints from "members of community boards and private citizens at meetings attended by precinct commanders," the unit targeted primarily highly trafficked public spaces and parks in workplace and tourist neighborhoods: Times Square, the Financial District, and Bryant and Washington Square Parks. ${ }^{61}$ A year before Kelling and Wilson's article presented its theoretical rationale for doing so, Koch envisioned a "broader [campaign] against 'quality-of-life' offenses." ${ }^{62}$

As these initiatives were unfolding, neighborhood organizations called for official action against open-air drug markets. Perhaps the most sustained campaign came from the Lower East Side, a neighborhood undergoing both disinvestment and gentrification. ${ }^{63}$ The Lower East Side market illustrated particularly clearly how informal economies developed as features of disinvestment and austerity. Using empty tenement buildings as staging grounds, the Lower East Side drug market leveraged the landscape of disinvestment; and as the city's largest Spanish-language newspaper observed, in the age of deindustrialization and a declining public sector, the industry represented an "integral part" of the neighborhood economy-as an industry, it was among the neighborhood's largest employers, particularly for young people (on the

\footnotetext{
${ }^{56}$ McGuire to Koch, May 12, 1982, Koch Papers, microfilm roll 26, folder 12, box 66, NYMA.

${ }^{57}$ Weiman and Weiss, "The Origins of Mass Incarceration in New York State," 92. On the Koch coalition, see John Mollenkopf, A Phoenix in the Ashes: The Rise and Fall of the Koch Coalition in New York City Politics (Princeton, NJ, 1992); and Soffer, Ed Koch and the Rebuilding of New York City, especially chs. 8-10, 12, 14.

${ }^{58}$ Soffer, Ed Koch and the Rebuilding of New York City, 320.

${ }^{59}$ Barbara Basler, "Koch Is Asking Why Justice System Fails," NYT, Oct. 8, 1980, 1.

${ }^{60}$ Angel Castillo, "12 Koch Criminal-Reform Changes Backed and 10 Disapproved by Bar,” NYT, June 4, $1981,1$.

${ }^{61}$ Leonard Buder, "New Police Unit to Battle Drugs in Public Places," NYT, July 31, 1981, 1.

${ }^{62}$ E. R. Shipp, “City Makes a Big Issue of Little Crimes," NYT, Aug. 30, 1981, 6.

${ }^{63}$ On the Lower East Side real estate market in the early 1980s, see Neil Smith, The New Urban Frontier: Gentrification and the Revanchist City (New York, 1996), ch. 9; and Christopher Mele, Selling the Lower East Side: Culture, Real Estate, and Resistance in New York City (Minneapolis, MN, 2000), ch. 7.
} 
Lower East Side, predominantly Puerto Rican) hit hard by the disappearance of manufacturing and government jobs. ${ }^{64}$ With decent transit connections and proximity to wealthier neighborhoods, it served a predominantly middle class clientele with heroin and, increasingly, with cocaine.

By the early 1980s, the Lower East Side drug market was growing quickly, drawing business from Central Harlem. ${ }^{65}$ In response, Manhattan Borough President Andrew Stein issued a report entitled "Illegal Drugs on the Lower East Side: A Call for City Action," which immediately spurred Koch to create a Lower East Side Narcotics Task Force. ${ }^{66}$ When stepped up enforcement efforts failed to curtail the market's growth, residents took to the streets in a series of marches and candlelight vigils. In March 1983, some 300 protesters-a coalition of block organizations, religious congregations, and other community groups-paraded from First Avenue and East 9th Street to Mayor Koch's apartment building in Greenwich Village. ${ }^{67}$

At the same time, the budgetary constraints of the 1970s and early 1980s had begun to loosen. With the financial and real estate sectors growing rapidly, New York City's expenditures grew (in real terms) by 24 percent between Fiscal Year 1981 and Fiscal Year $1985{ }^{68}$ The city's fiscal recovery permitted the NYPD to hire some 12,000 new officers, roughly the number it had lost to the fiscal crisis. ${ }^{69}$

Neighborhood-level discontent and loosening fiscal constraints opened the door for the city's first sustained campaigns against open-air drug markets since the early 1970s. In January 1984, McGuire's successor, Benjamin Ward, launched a new campaign to "retake" selected public spaces through a highly visible and publicized policing initiative. ${ }^{70}$ The program, "Operation Pressure Point" (OPP), launched with more than 200 police officers descending on the Lower East Side "to clean up" New York's “'supermarket' of illegal drugs," primarily through the use of buy-and-bust arrests. ${ }^{71}$ Several months later, the NYPD launched a second OPP campaign in Central Harlem. ${ }^{72}$ With these campaigns, New York made a highly visible, sustained commitment to "quality of life"-style policing, focusing particularly on open-air drug markets.

\footnotetext{
64"Limpieza policiaca de traficantes de drogas," El Diario-La Prensa, Jan. 20, 1984, 28.

${ }^{65}$ “En dos años aumentará la venta de droga en NY," El Diario-La Prensa, Jan. 19, 1984, 3; "Policía realiza 1.300 arrestos por drogas en Lower East Side," El Diario-La Prensa, Feb. 7, 1984. On the Lower East Side drug market, see Lynn Zimmer, Operation Pressure Point: The Disruption of Street-Level Drug Trade on New York's Lower East Side (New York, 1987), 2-4; and Eric Schneider, Smack: Heroin and the American City (Philadelphia, 2008), ch. 10. Though an outgrowth of disinvestment, the drug economy also helped finance new legitimate businesses and the construction of upmarket co-op housing. See Nicholas Pileggi, "There's No Business Like Drug Business," New York Magazine, Dec. 13, 1982, 39-40.

${ }^{66}$ Andrew Stein to Koch, June 8, 1982 (enclosing report), Koch Papers, NYMA; Koch to Stein, June 30, 1982, Koch Papers, microfilm roll 4, folder 9, box 17, NYMA.

${ }^{67}$ Rob DeRocker, "Lower East Side Groups Gear Up for March Urging Stronger War on Drug Traffic There," The Villager, Mar. 10, 1983; Jeanne Jackson, "Lower East Siders Take Back Their Streets," The Villager, Mar. 24, 1983.

${ }^{68}$ City of New York, Office of the Comptroller, Comprehensive Annual Report of the Comptroller for the Fiscal Year Ending ... (New York, 1981 and 1985).

${ }^{69}$ Kane and White, Jammed Up, 50-1.

${ }^{70}$ Ward himself emphasized OPP's visibility and publicity when discussing it as a policing strategy. See Benjamin Ward, "Police/Public Consultation: A Perspective from Police Commissioner Benjamin Ward," in Models of Police/ Public Consultation in Europe (Cranfield-Wolfson Colloquium, 1984), Koch Papers, microfilm roll 108, folder 10, box 230, NYMA.

71 "Police Moving to Halt Drug Sales on Streets of the Lower East Side," NYT, Jan. 20, 1984; "Limpieza policiaca de traficantes de drogas," 2, 28; Carroll, "Operation Pressure Point: An Urban Drug Enforcement Strategy," FBI Law Enforcement Bulletin 58, no. 4 (Apr. 1989): 1-7, details how OPP worked in operation. The initial campaign focused on the area from 14th Street and Delancey Street, Avenue A and Bowery in the west to Avenue D and Columbia Street to the east, with particular attention on Rivington, Eldridge, and Forsyth Streets, 2nd-4th Streets, and Avenues B and C.

${ }^{72}$ Craig Wolff, "Three Agencies Joining Police in Drive on Drugs in Harlem," NYT, Feb. 26, 1984, 39; Koch to Ward, Mar. 5, 1984; Ward to Koch, Mar. 13, 1984, Koch Papers, microfilm roll 51, folder 1, box 119, NYMA.
} 
Operation Pressure Point was primarily the idea of Commissioner Ward, whom Koch had appointed at the beginning of 1984 following a congressional investigation into police brutality in New York. Ward, who had grown up in Weeksville, Brooklyn, and had joined the NYPD as a patrolman in 1951, became the city's first Black police commissioner. ${ }^{73}$ By his own recollection, Ward was embarrassed by the presence of the huge open-air drug market he saw on his daily commute from Queens to One Police Plaza-and was particularly distressed that European news film crews were shooting it as evidence of "the typical American scene."74 "I saw it as a problem that needed to be solved in some way," he recalled. ${ }^{75}$ Ward faced some initial resistance from within the NYPD. Some managers harbored lingering fears of corruption; some officers viewed the open-air markets as places to boost their arrest numbers-a resource rather than a problem. ${ }^{76}$ Mayor Koch, whose support Ward felt he needed to ensure himself the resources OPP required, told Ward to go ahead with the program even though he thought it unlikely to work- "the courts are going to let them go," Ward remembered Koch saying. ${ }^{77}$ Ward ascribed Koch's subsequent strong support to the fact that the operations garnered positive press and that community groups pushed for stronger antidrug market measures. ${ }^{78}$

Operation Pressure Point quickly stirred up opposition from churches and community groups. Still fearing corruption, the NYPD deployed patrolmen with little experience in the neighborhood; many of the officers were recent graduates of the police academy, part of the hiring spree of the early 1980 s. $^{79}$ Unsurprisingly, community leaders found that officers "[couldn't] tell the good guys from the bad guys" and were "grabbing our children ... because they think everyone black and Hispanic is a drug dealer...." "Some residents admitted," an internal NYPD study found, "that they are frequently more fearful of the officers than the addicts and dealers." ${ }^{\prime 1}$ Both Koch and the NYPD believed that most of the drug dealers chased off the streets by OPP simply moved-to nearby streets, into the subways, into public housing projects, from one park to another. ${ }^{82}$

Even so, OPP became a political success for Koch. Local media coverage was "nothing but favorable." 83 One of the city's leading tabloids, the New York Daily News, ran a two-page photo spread lauding Koch and the NYPD for "giving the ABCs back to the neighborhood," complete with action shots of surveillance, searches, and arrests and a shot of Koch and Ward inspecting a collection of seized drugs and weapons. ${ }^{84}$ The New York Times ran a similarly illustrated feature. ${ }^{85} \mathrm{~A}$ year into the first OPP campaign, Koch could cite not only arrest statistics, but also sharply

\footnotetext{
${ }^{73}$ For Ward's fascinating biography, see Soffer, Ed Koch and the Rebuilding of New York City, 335-7.

${ }^{74}$ Oral history interview with Benjamin Ward (1992), Edward I. Koch Administration Oral History Project, 109110, Oral History Archives at Columbia, Rare Book \& Manuscript Library, Columbia University in the City of New York. On New York elites' concern with media depictions of their city in the post-crisis years, see Greenberg, Branding New York.

${ }^{75}$ Oral history interview with Benjamin Ward, 120.

${ }^{76}$ Richard Curtis, "The War on Drugs in Brooklyn, New York: Street-Level Drug Markets and the Tactical Narcotics Team" (Ph.D. diss., Columbia University, 1996), 21; Oral history interview with Benjamin Ward, 120.

${ }^{77}$ Soffer, Ed Koch and the Rebuilding of New York City, 349.

${ }^{78}$ Ibid., 118, 120, 128.

${ }^{79}$ Curtis, "The War on Drugs in Brooklyn," 20; Kane and White, Jammed Up, 50-2.

${ }^{80}$ Oral history interview with Benjamin Ward, 112.

${ }^{81}$ Jeanne Mulgrav, "Operation Pressure Point: A Community Perspective," in Curtis, "The War on Drugs in Brooklyn, New York," 20-1.

${ }^{82}$ Brendan Sexton to Stanley Brezenoff, July 17, 1985, Koch Papers, microfilm roll 51, folder 2, box 119, NYMA; Marcia Chambers, "Going Cold Turkey in Alphabetville," NYT, Feb. 19, 1984, 7; Jane Gross, "In the Trenches of a War Against Drugs," NYT, Jan. 8, 1986, B1; Esther B. Fein, "In Lobby of Lower East Side Project, Tenants Draw Line Against Addicts," NYT, Apr. 14, 1986, B1.

${ }^{83}$ Lynn Zimmer, "Proactive Policing Against Street-Level Drug Trafficking," American Journal of Police 9, no. 1 (1990): 43-74, here 64 .

84"Giving the ABCs Back to the Neighborhood," New York Daily News, Jan. 20, 1984.

${ }^{85}$ Craig Wolff, "Drug Arrests Mounting on the Lower East Side," NYT, Mar. 5, 1984, B1.
} 
declining robbery and homicide rates in the neighborhoods covered, and even in adjoining ones. ${ }^{86}$ Armed robberies had decreased by 47 percent and homicides by 60 percent on the Lower East Side; in Harlem, the second staging area, robberies fell by some 39 percent in the first eleven months of OPP $2 .{ }^{87}$ Statistics like these eluded the questions of whether crime simply moved, whether falling rates of violent crime in the staging areas were due to the OPP campaigns or caused by some other set of factors, and whether they were permanent or merely temporary. But decontextualized, statistics like these provided a language with which Koch and the NYPD could assert the city government's competency at a moment when it had little success decreasing crime city-wide.

In 1986, when Koch and Harlem Congressman Charlie Rangel mobilized America's big-city mayors to pressure the Reagan administration to devote more resources to the war on drugs (which the U.S. Conference of Mayors assailed as "grossly underfunded"), they pointed to OPP as a local success story-a model that could be scaled up if the federal government supplied the fiscal resources. ${ }^{88}$ "[I]t is clear that Operation Pressure Point is a tremendous success which may show the way for controlling the epidemic of dangerous drugs that threatens our nation," Koch wrote in an op-ed. "Is it not ... correct to say that Americans could stop the drug epidemic in America if we really wanted to? I believe that Operation Pressure Point has demonstrated what can be done ... in American cities." 89

A number of Koch's progressive adversaries concurred. When, in 1985, City Council President Carol Bellamy (who also ran in the general election on the Liberal Party line) challenged Koch in the Democratic primary, she called for more police officers and for a city-wide extension of OPP. ${ }^{90}$ Policy intellectuals, too, suggested that OPP might serve as a model. Mark H. Moore lauded the NYPD for finally putting his ideas into practice. ${ }^{91}$ James Q. Wilson (who had presaged such arguments in Thinking About Crime) likewise argued that demand could be rendered elastic, because some sellers had territory they felt comfortable with and would be reluctant to move. ${ }^{92}$ Mark A. R. Kleiman, a research fellow at the Kennedy School, argued that by raising the cost to buyers of "looking for a safe place to buy" and to sellers of "looking for customers they can trust," "fewer drugs will change hands." 93

Community-level political leaders and organizations in other neighborhoods had yet to see firsthand the civil liberties abuses wrought by OPP. But they well understood the threat streetlevel drug markets (and drug markets operating in abandoned housing) posed to their own neighborhood-based community building projects, especially their efforts to rebuild their housing stock following the arson and abandonment of the 1970s. For these reasons, the NYPD's expansion of OPP and similar initiatives often garnered the support of neighborhood leaders-indeed, it sometimes came at their insistence. In the spring of 1985, Councilman Fernando Ferrer of the Bronx got in touch with Deputy Mayor for Operations Stan Brezenoff to propose a Pressure Point area in his district. ${ }^{94}$ When the NYPD launched a related

\footnotetext{
${ }^{86}$ Koch, "Stopping the Drug Epidemic" (op-ed draft, Mar. 20, 1984), Koch Papers, microfilm roll 51, folder 2, box 119, NYMA.

${ }^{87}$ Jesus Rangel, "Police Laud East Side Drug Drive," NYT, Apr. 23, 1985, B3; Esther B. Fein, "Crime Drop Cited in Area of Drug Crackdown," NYT, Jan. 27, 1985, 24.

${ }^{88}$ Koch to Rangel, July 18, 1986, Koch Papers, microfilm roll 52, folder 7, box 120, NYMA; Mayor's Office, Press Release, July 18, 1986, Koch Papers, microfilm roll 52, folder 5, box 120, NYMA; “Critics Say No to Reagan's Drug Policy," Black Enterprise 19, no. 1 (1988), 29.

${ }^{89}$ Koch, "Stopping the Drug Epidemic" (op-ed draft, Mar. 20, 1984), Koch Papers, microfilm roll 51, folder 2, box 119, NYMA.

90"Bellamy, in Anticrime Paper, Calls for Police to Ride Every Subway Train," NYT, July 24, 1985, B3.

${ }^{91}$ Chambers, "Going Cold Turkey in Alphabetville."

${ }^{92}$ Todd S. Purdum, "Police Dilemma on Restaurant Row," NYT, June 14, 1988, B2.

${ }^{93}$ Peter Kerr, "War on Drugs Shifting Focus to Street Deals," NYT, Apr. 13, 1987, 1.

${ }^{94}$ Fernando Ferrer to Brezenoff, Apr. 4, 1985, Koch Papers, microfilm roll 108, folder 10, box 230, NYMA. See Noël Wolfe, "Battling Crack: A Study of the Northwest Bronx Community and Clergy Coalition's Tactics," Journal of Urban History 43, no. 1 (Jan. 2017): 18-32.
} 
program called Operation Closedown to "spur the eviction of tenants" convicted of selling narcotics in Crown Heights, both the local community board and Congressman Major Owens applauded-“I've been wondering when our turn would come," Owens remarked. ${ }^{95}$ In 1985, a coalition of "homeowners, tenant groups, block associations, and churches" in the West Bronx staged a series of marches and demonstrations that led to meetings between the NYPD and community leaders, and then to "additional foot patrol on streets with the heaviest activity and with selective attention to several specific vending locations." ${ }^{\prime 96}$ In Brownsville and East New York, Reverend Johnny Ray Youngblood of the East Brooklyn Churches coalition pressured the NYPD (through Koch) to take stronger action against the "plague of drug locations in our area"; the NYPD in response promised to make "a strong, good faith effort ... to close 40 drug locations by the end of 1985." Everywhere, Ward found, favorable media coverage raised public expectations. "[E]veryone wants their own Pressure Point," he said. ${ }^{98}$ The NYPD even struggled to withdraw from its original campaign on the Lower East Side because it had "raised community expectations" with regard to what the police can accomplish. ${ }^{99}$

New York City's shift toward street-level drug policing occurred only when new policing ideas, popular dissatisfaction with street crime, and the revival of the city's fiscal capacity coalesced as part of a larger project to rebuild urban governance in the aftermath of the fiscal crisis of the 1970s. Street-level drug enforcement promised to assert the competence of the local state, which had been cast into doubt by the experiences of the 1970s and the rise of private alternatives to what had been public functions: it allowed the city to do something about crime at a time when the NYPD had had relatively little success at reducing rates of serious crime. By reclaiming public spaces from the drug economy, the local state could also seek to restore an idealized vision of cosmopolitan street life; it could aim to reconstruct a neighborhoodsituated social order built around middle-class norms and legitimate economies, which in turn would permit the NYPD to leverage citizen surveillance to build a governing capacity it could hardly possess on its own. ${ }^{100}$ And by doing these things, it could take an important step toward restoring the fiscal and economic well-being of the city and its neighborhoods.

Much as the punitive turn of the 1970s "tapp[ed] into a vein of public opinion furious about the alleged incompetence of liberal crime control strategies," so may the policing practices of the 1980s be understood as an effort to reassert the local state's competence in light of the failure of the crime control strategies of the 1970s. ${ }^{101}$ Whatever the Rockefeller laws had done, they had not substantially reduced property crime or street violence, and they had not tipped the balance in local struggles between "legitimate" and "illegitimate" users of public space. The failure of state (and federal) drug policies and the municipal austerity regime of the 1970s had created space for a host of market- and community-based security solutions, some of which, like the Guardian Angels, represented a challenge to the state's authority and an everyday reminder of the state's incompetence. ${ }^{102}$ It had also left the local state exposed to community-

\footnotetext{
${ }^{95}$ William R. Greer, “51 Are Seized in Storefront Raids in Brooklyn,” NYT, Apr. 7, 1984, 29.

${ }^{96}$ Dimas Planas Belfort, et al., to Ward, Mar. 30, 1985, Koch Papers, microfilm roll 108, folder 10, box 230, NYMA; Ward to Brezenoff, Aug. 8, 1985, Koch Papers, microfilm roll 108, folder 1, box 231, NYMA.

${ }^{97}$ Johnny Ray Youngblood to Koch, July 3, 1985, Koch Papers, microfilm roll 108, folder 11, box 230, NYMA; Youngblood to Koch, July 17, 1985, Koch Papers, microfilm roll 108, folder 11, box 230, NYMA; Youngblood to Ward, Sept. 5, 1985, Koch Papers, microfilm roll, 108, folder 1, box 231, NYMA.

${ }^{98}$ Zimmer, Operation Pressure Point, 16.

${ }^{99}$ Ibid.

${ }^{100}$ Holtzman, "Expanding the Thin Blue Line," 59-62, details the NYPD's efforts to leverage civilian volunteers as "extended eyes and ears" in the aftermath of the mid-1970s layoffs.

${ }^{101}$ Kohler-Hausmann, “'The Attila the Hun Law," 88.

${ }^{102}$ On the Guardian Angels, see Reiko Hillyer, "The Guardian Angels: Law and Order and Citizen Policing in New York City," Journal of Urban History 43, no. 6 (Nov. 2017): 886-914. Alex Vitale notes that the rise of business
} 
level demands for a kind of policing that would support the normative uses of public space the political establishment claimed were so vital to the city's well being.

Street-level drug markets became a problem not just because they were linked to a rising discourse of community "order," but also because they came paired with a feasible, ready-made solution. The long-range effectiveness of this solution may have been dubious. But nonetheless it was something the city government could do that would produce immediate, visible, highly publicized results; and moreover, the discourse of statistics afforded a language with which potentially dubious claims of state competency could be legitimized. For Koch, the "plague of street dealers" targeted by OPP represented "the transcendent urban problem of our time" because it had become "a dreary symbo[1] of human failure," evoking in people "a sense of despair and contempt for the ability of law and government to deliver them from crime and addiction." ${ }^{103}$ Ward's seemingly bland statement to newspaper reporters the morning of OPP's launch suggested that the NYPD, too, felt the need to make a public demonstration of its own capability and competence: "I can't not do anything," he remarked. "I must do something."104

The policy departures of the early-to-mid-1980s must also be understood in the context of a broad effort in the wake of the 1970s economic crisis to restore (or "stabilize") public spaces by making them more amenable to normative uses. ${ }^{105}$ To Ward, accessible public space was fundamental to a good city, for it provided "access to those city amenities (parks, museums, libraries, theatres, etc.) that enrich and define urban living...."106 This emphasis on the value of public space, however, worked in concert with a longstanding discourse, dating from the 1960s and particularly pronounced from the mid-1970s onward, on the need to attract and maintain a tax-paying middle class. Both Koch and Ward envisioned New York's "urban crisis" as, in part, a product of the middle classes' withdrawal from urban spaces and neighborhoods; they assumed the city's recovery depended upon the restoration of the middle classes and the modes of social control Koch and Ward believed a middle class presence enabled.

The key to restoring public spaces, city officials believed, lay in encouraging a visible presence of normatively behaving people within them: once such people had become predominant in a particular public space, the theory went, they could enforce social norms-citizen surveillance would effectively extend the NYPD's order-maintenance capacity. The social thinking that underpinned this approach dated back at least to the 1960s, when urbanists such as Jane Jacobs had introduced the concept of "eyes on the street," an idea extended by William $\mathrm{H}$. Whyte in the early 1980s and embraced by the emerging parks conservancies and business improvement districts. ${ }^{107}$ An idealized notion of community self-regulation also informed Kelling and Wilson's broken windows theory and the rising law enforcement paradigm of community policing, which cast police departments and communities as "co-producers" of public

improvement districts "challenged the police's institutional domain by providing an alternative example of how to reduce crime and restore order, by directly replacing some of the police's central functions." Vitale, City of Disorder, 128-9, here 129. Benjamin Holtzman stresses the NYPD's close connections with private security forces, particularly the better-resourced BIDs: "Not only were security firms and patrols commonly led by former police officials, but security guards themselves could even be police after the department ended its prohibition on officers working as guards in 1984" (Holtzman, "Expanding the Thin Blue Line," 65).

${ }^{103}$ Edward Koch, "Needed: Federal Antidrug Aid," NYT, Apr. 27, 1984, 27.

${ }^{104}$ David W. Dunlap, "Police Move to Halt Drug Sales on Streets of the Lower East Side," NYT, Jan. 20, 1984, B2.

${ }^{105}$ In this respect, street-level enforcement was of a piece with the concurrent private/public renovations of the city's parks. On the Central Park Conservancy, see Roy Rosenzweig and Elizabeth Blackmar, The Park and the People: A History of Central Park (Ithaca, NY, 1992), 499-530.

${ }^{106}$ Ward to Koch, Apr. 4, 1984, Koch Papers, microfilm roll 15, folder 1, box 36, NYMA.

${ }^{107}$ William H. Whyte, "Revitalization of Bryant Park-Public Library Front," Memorandum to the Rockefeller Brothers Fund, Nov. 26, 1979, folder 18, box 1, William H. Whyte Papers, Rockefeller Archive Center, Sleepy Hollow, NY; William H. Whyte, The Social Life of Small Urban Spaces (New York, 1980), 60-4. 
safety. ${ }^{108}$ With respect to street-level drug markets, the task of the police within this framework was to re-regulate public space such that small-time sellers became seen as neighborhood "outsiders." Ward, in particular, envisioned street-level drug enforcement as the first phase of a police-"community" partnership that would reconstruct "community-based" social control and behavioral standards: "We try to mobilize the community to take charge of their neighborhood, once we get the outsider/drug dealers out of there." ${ }^{109}$ Where OPP was most successful, an early study noted, buyers and sellers did indeed become “'outsiders,' their presence readily apparent to OPP personnel and to residents, many of whom were eager to report them to the police." 110 (The NYPD set up special drug complaint hotlines to facilitate precisely that. ${ }^{111}$ )

Though Ward in particular would not have conceived of it as such, the project of "restoring" public spaces was inescapably racialized. To the degree that it involved the influx of more affluent people to neighborhoods that had seen historic disinvestment, it required the whitening of those neighborhoods. And in the context of ongoing racial bias in policing, it would result in the displacement, not only of people actually involved in illegitimate economic activities, but also of people who simply belonged to social categories the police associated with illegitimate economic activities, effectively designating a wider range of public spaces as (in the sociologist Elijah Anderson's conceptualization) "white space"-places “informally 'off limits."'112

The class and racial logics of spatial re-regulation ensured that, in neighborhoods with hot real estate markets, debates over street-level drug policing became bound up in larger contests over gentrification. Initially, neighborhood activists and block associations had viewed streetlevel drug enforcement as a tool in the fight against gentrification. Some participants in the 1983 East Side antidrug marches had held signs that said "Stop Gentrification"; one woman had explained to the Greenwich Village community paper The Villager that residents felt their neighborhood had been "zoned for drugs" so as to break down community resistance to redevelopment. ${ }^{113}$ By 1985, this language had largely vanished, and many Lower East Siders had come to view OPP as part of a broader effort to make their neighborhood safe for the forces of gentrification. The Lower East Side Joint Planning Council professed that, while they were "grateful when drug traffic is under control," they "are convinced safe streets for Lower East Side residents was not the objective of this police crackdown." Rather: "As rising rents and the new boutiques attest, the area is being made safe for well-heeled outsiders, not the working-class people who have traditionally lived here." ${ }^{\prime 14}$ As the campaign unfolded, voices could be heard applauding what the city was doing as a way of improving real estate markets. "Not only are young couples coming in because of it," noted one real estate agent, "but parents are buying apartments for their sons or daughters attending N.Y.U." 115 A feature in the Sunday New York Times made it practically official: "The Fortunes of the Lower East Side Are Rising," the headline read: "Thanks to Operation Pressure Point, Art Galleries Are Replacing Shooting Galleries." 116

\footnotetext{
${ }^{108}$ Jerome Skolnick and David Bayley, The New Blue Line: Police Innovation in Six American Cities (New York, 1986), 213.

${ }^{109}$ Oral History interview with Benjamin Ward, 116.

${ }^{110}$ Ibid., 63.

${ }^{111}$ Carroll, "Operation Pressure Point," 3-4.

${ }^{112}$ Elijah Anderson, "The White Space," Sociology of Race and Ethnicity 1, no. 1 (Jan. 2015): 10-21, here 10.

113"Lower East Siders Take Back Their Streets," The Villager, Mar. 24, 1983. See also Luc Sante, "My Lost City," New York Review of Books, Nov. 6, 2003, https://www.nybooks.com/articles/2003/11/06/my-lost-city/ (accessed Sept. 28, 2020).

${ }^{114}$ Frances Goldin, “The Yupping of Avenue A,” NYT, Aug. 30, 1985, 24.

${ }^{115}$ Ibid.

${ }^{116}$ William R. Greer, “The Fortunes of the Lower East Side Are Rising,” NYT, Aug. 4, 1985, E6.
} 
Ward hated the idea of himself as an agent of gentrification, and there exists no particular reason to doubt his claims that gentrification per se was not an objective of OPP. ${ }^{117}$ Yet in practice, the project of "stabilizing" communities by re-regulating public spaces was inescapably bound up with the processes of neighborhood transition, and it was no accident that the Pressure Point campaigns saw their greatest success in gentrifying neighborhoods. While not the aim of street-level drug enforcement, gentrification was a wholly foreseeable consequence, facilitated by the very logic of the NYPD's governing strategies.

As street-level drug policing spread from the Lower East Side to encompass neighborhoods across the city, the number of felony drug arrests soared, returning to the levels reached during the abandoned street-policing experiment of the late-1960s and early-1970s. As a consequence of these local policy shifts, nearly three times as many people were now being fed into the legal regime established by the Rockefeller laws-since modified, but still highly punitive (Table 2, Figures 1-3).

Crack cocaine's rising popularity in 1985 and 1986 only deepened New York City's commitment to street-level drug policing. ${ }^{118}$ The fact that crack's proliferation corresponded with a reversal of four years of declining crime statistics-a development that was, Ward lamented to Deputy Mayor Stan Brezenoff, receiving "considerable media attention"-produced strong pressures within the administration and from the press for a vigorous, aggressive official response. ${ }^{119}$ Moreover, the NYPD and the Koch administration quickly theorized a relationship between crack and rising crime rates (which turned on the brevity of the crack "high" and the addictive qualities of the drug). ${ }^{120}$

Equipped with these motives and rationales, the city initiated a new round of street policingorganizing Tactical Narcotics Teams (TNT), which "flood[ed] the streets" of selected neighborhoods with undercover officers who conducted buy-and-bust operations. ${ }^{121}$ The operation differed from OPP in that it focused specifically on crack and did not entail a visible uniformed presence. But as the closest study of the program notes, Koch and Ward launched the program despite "persistent skepticism within the NYPD and among government officials that [street-level drug policing] was anything more than a 'numbers game," in large measure because "the results of Operation Pressure Point suggested that TNT had a good chance of being seen by the public as successful." ${ }^{\prime 22}$ Ward also created a new, special Anti-Crack Unit and, acting on the assumption that crack represented a more dangerous commodity than previous drugs, city officials also launched "a campaign to make more arrests that would hold up in court as serious felonies."

\footnotetext{
${ }^{117}$ Oral History interview with Benjamin Ward, 112-4. Perhaps at Ward's insistence, the coordinator of the Lower East Side OPP campaign wrote a Times op-ed assailing pro-gentrification housing policies. See Patrick Carroll, "Lower East Side Did Not Win in Order to Lose," NYT, Jan. 12, 1985. Smith, The New Urban Frontier, 206, which describes the Lower East Side OPP campaign as "gentrification-induced."

${ }^{118}$ On the history of crack in American cities, see David Farber, Crack: Rock Cocaine, Street Capitalism, and the Decade of Greed (New York, 2019).

${ }^{119}$ Ward to Brezenoff, May 26, 1986, Koch Papers, microfilm roll 15, folder 9, box 38, NYMA.

${ }^{120}$ Ward to Brezenoff, May 23, 1986, Koch Papers, microfilm roll 108, folder 4, box 231, NYMA; Brezenoff to Ward, June 17, 1986, Koch Papers, microfilm roll 108, folder 4, box 231, NYMA. See also Francis C. Hall, "Crack Briefing for the Mayor," July 23, 1986, Koch Papers, microfilm roll 108, folder 4, box 231, NYMA.

${ }^{121}$ George James, "Drug Crackdown Is Expanded to East Harlem,” NYT, Nov. 16, 1988, 1. On TNT, see Curtis, "The War on Drugs in Brooklyn, New York."

${ }^{122}$ Curtis, "The War on Drugs in Brooklyn, New York," 28-9. Ward himself credited OPP with giving the NYPD a head start in policing crack. See Peter Blauner, "Big Ben: Has Police Commissioner Ward Become a Liability to Koch?” New York Magazine, Apr. 3, 1989, 52.

${ }^{123}$ Ward to Brezenoff, May 23, 1986, Koch Papers, microfilm roll 108, folder 4, box 231, NYMA; Brezenoff to Ward, June 17, 1986, Koch Papers, microfilm roll 108, folder 4, box 231, NYMA; “The Crack Crackdown's Jail Backlash,” NYT, Oct. 22, 1986, 30.
} 
Table 2. Felony drug arrests in New York City, 1978-1989 (Office of Information Technology Services, "Adult Arrests 18 and Older by County: Beginning 1970," https://data.ny.gov/Public-Safety/Adult-Arrests-by-CountyBeginning-1970/rikd-mt35, accessed Aug. 2, 2019. See Figures 1-3 for drug felony and misdemeanor arrests by borough, 1970-2018.

Felony drug arrests

\begin{tabular}{ll}
\hline 1978 & 7,972 \\
\hline 1979 & 8,879 \\
\hline 1980 & 8,740 \\
\hline 1981 & 12,363 \\
\hline 1982 & 14,475 \\
\hline 1983 & 15,988 \\
\hline 1984 & 20,183 \\
\hline 1985 & 20,994 \\
\hline 1986 & 29,687 \\
\hline 1987 & 36,058 \\
\hline 1988 & 43,449 \\
\hline 1989 & 48,968 \\
\hline
\end{tabular}

In the first years of OPP, the odds were "overwhelming" that a person arrested for buying, selling, or carrying drugs in an NYPD street sweep would not go to prison. ${ }^{124}$ Only 37 percent of drug arrests resulted in felony charges, and only one-third of those arrests led to indictments. ${ }^{125}$ Yet the sheer number of arrests produced by street-level drug policing quickly added up, and over time, repeat arrests left sellers and buyers exposed to more severe penalties. After 1985, city efforts to make crack arrests stand up in court; investment by the city, state, and federal governments in prosecutorial, court, and carceral capacities; and, likely, a hardening of attitudes toward drug offenses on the part of judges further swelled the incarcerated population. ${ }^{126}$ New York Governor Mario Cuomo and the state legislature accommodated the rise of mass incarceration by financing new prison construction through the state's Urban Development Corporation, which could issue bonds without voter approval. ${ }^{127}$ Finally, Cuomo proposed and signed a strict anti-crack law, intended specifically to subject more smalltime sellers (many of whom were being arrested for misdemeanor possession) to Class D felony charges. ${ }^{128}$

\footnotetext{
${ }^{124}$ See Bernadette Fiore and Martha Schiff, Operation Pressure Point, 1/19/84-2/18/84: Final Report on Arrest Characteristics and Criminal Court Outcomes (New York, 1984).

${ }^{125}$ Roberta Kaye and Dynda Andrews to Koch and Patrick Mulhearn, July 24, 1986, Koch Papers, microfilm roll 108 , folder 4, box 231, NYMA.

${ }^{126}$ See Weiman and Weiss, "The Origins of Mass Incarceration in New York State," 97. On the role of prosecutors, see John Pfaff, Locked In: The True Causes of Mass Incarceration and How to Achieve Real Reform (New York, 2017). Additional historical research on prosecutors is badly needed.

${ }^{127}$ Jack Norton, "Little Siberia, Star of the North: The Political Economy of Prison Dreams in the Adirondacks," in Historical Geographies of Prisons: Unlocking the Usable Carceral Past, eds. Karen Morin and Dominique Moran (New York, 2015), 168-84. See also Saladin Ambar, American Cicero: Mario Cuomo and the Defense of American Liberalism (New York, 2018).

128“Crack Possession Law Is Stiffened in New York," NYT, June 30, 1988, B3. Koch characterized Cuomo's proposals as "a throwback to the harsh, but largely ineffective Rockefeller drug laws." Kevin Frawley to Koch, Koch Papers, microfilm roll 52, folder 8, box 120, NYMA.
} 


\section{Manhattan}

35,000

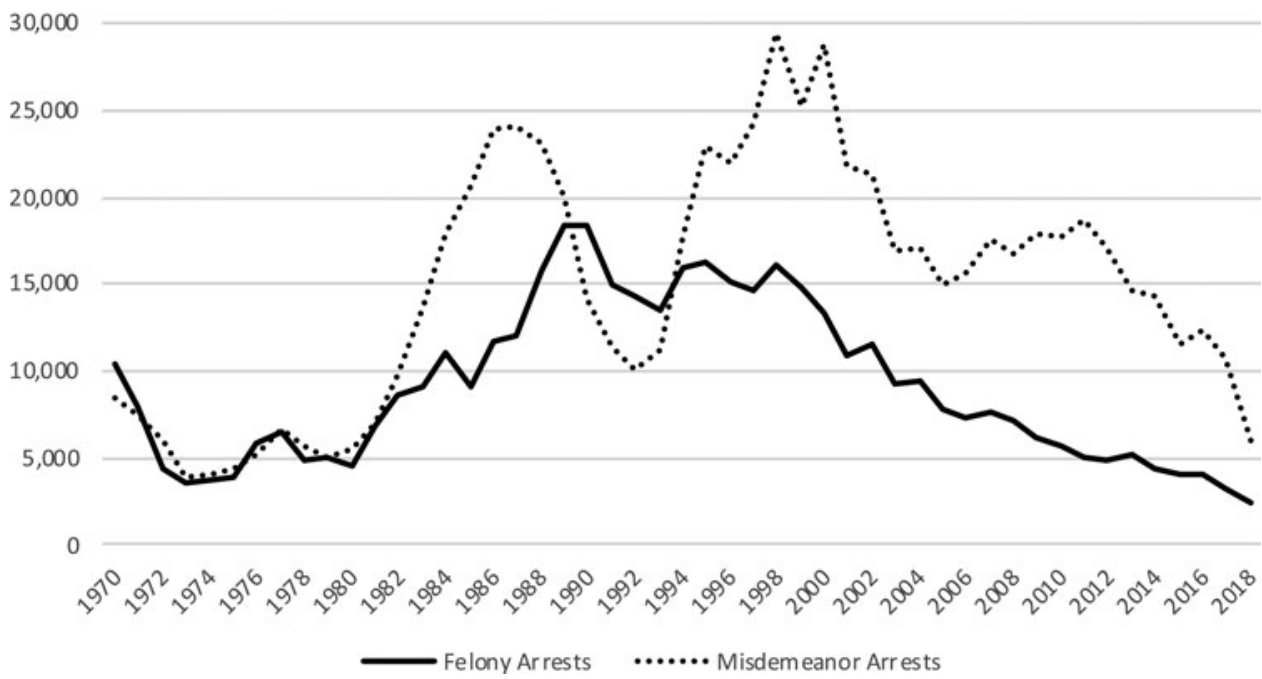

Figure 1. Drug arrests in Manhattan, 1970-2018. Office of Information Technology Services, "Adult Arrests 18 and Older by County: Beginning 1970," https://data.ny.gov/Public-Safety/Adult-Arrests-by-County-Beginning-1970/rikd-mt35, accessed Aug. 2, 2019.

\section{The Bronx}

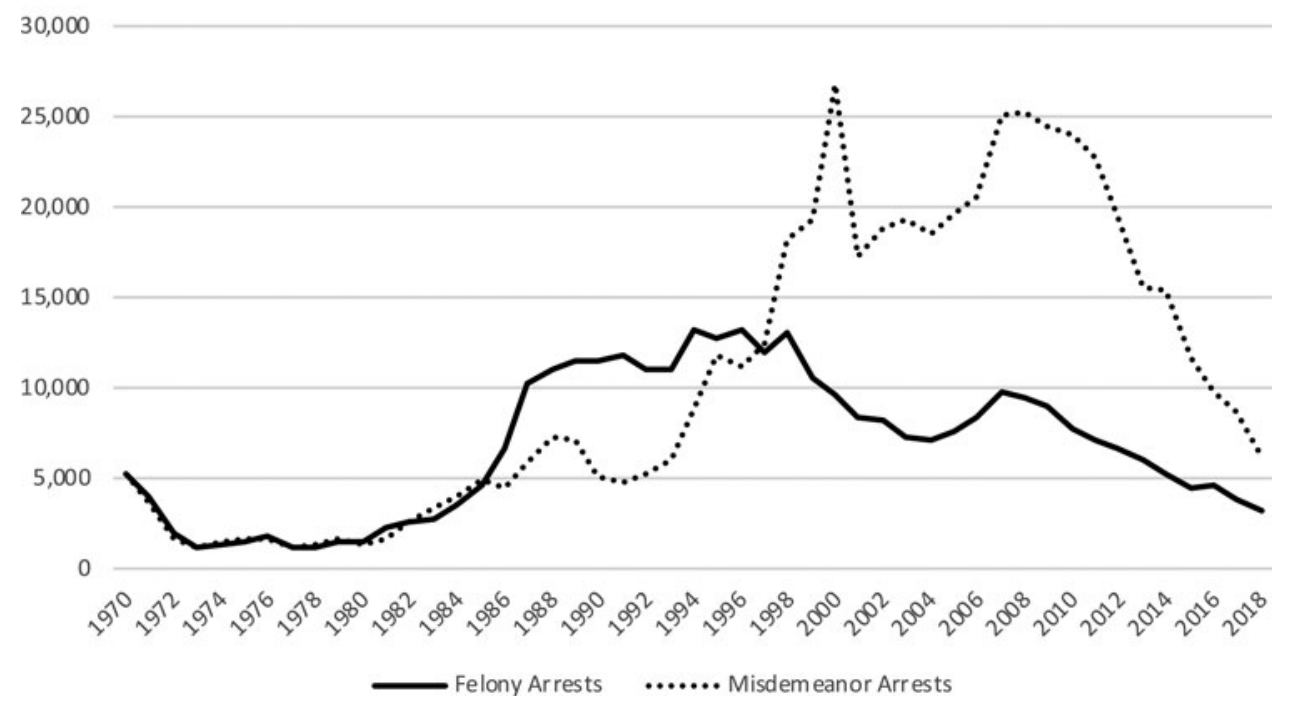

Figure 2. Drug arrests in the Bronx, 1970-2018. Office of Information Technology Services, "Adult Arrests 18 and Older by County: Beginning 1970," https://data.ny.gov/Public-Safety/Adult-Arrests-by-County-Beginning-1970/rikd-mt35, accessed Aug. 2, 2019.

On the eve of OPP, drug offenders had represented some 10 percent of New York State inmates; by the end of the decade, that figure neared 35 percent. These arrests had helped drive the state incarceration rate to roughly triple what it had been in Koch's first year in office.

By the time Koch and Ward left office in 1989, street-level drug policing was locked in-in spite of new revelations of police corruption reminiscent of the scandals that had contributed to 


\section{Brooklyn}

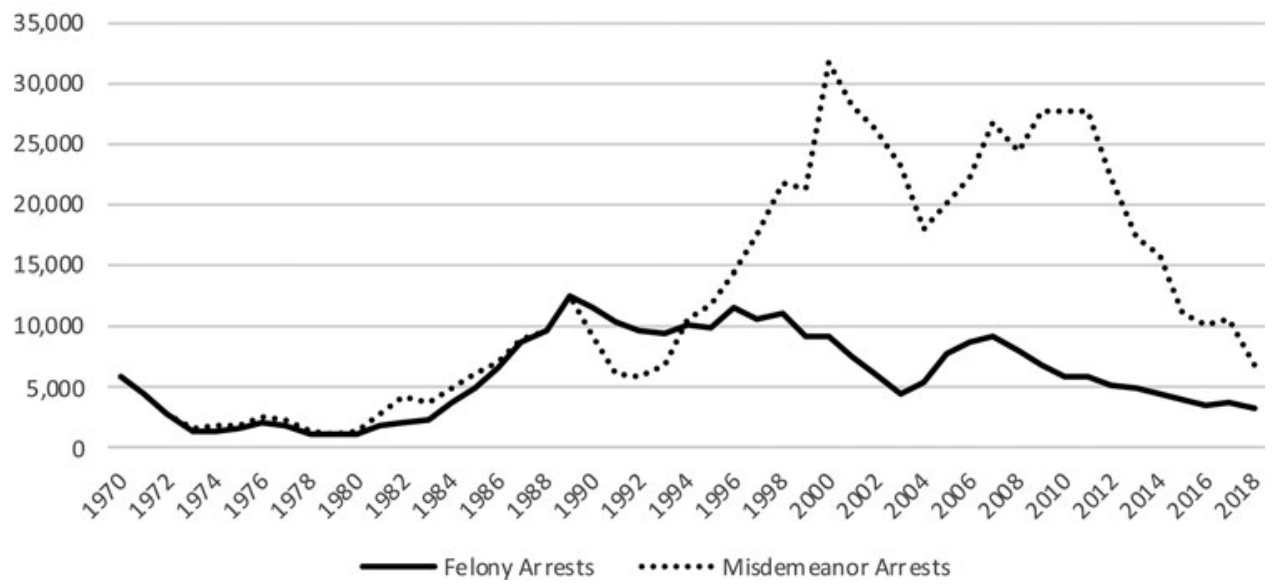

Figure 3. Drug arrests in Brooklyn, 1970-2018. Office of Information Technology Services, "Adult Arrests 18 and Older by County: Beginning 1970," https://data.ny.gov/Public-Safety/Adult-Arrests-by-County-Beginning-1970/rikd-mt35, accessed Aug. 2, 2019.

the NYPD's decision to step back from street-level enforcement in the early $1970 \mathrm{~s}^{129}$ Street-level drug policing formed one important aspect of a broader style of "quality-of-life" policing that sought to remove the symptoms of urban disinvestment, displacement, and poverty-not only drug markets, but also homelessness, street peddling, and other informal economies-less out of a theoretical conviction that addressing small crimes would prevent big ones than in response to the same political imperatives that had guided the city's turn toward street-level drug enforcement. ${ }^{130}$ David Dinkins, the liberal Democrat who pried Koch loose from City Hall in 1989, vowed to "retak[e] the city" from "the pushers and the muggers"; in the midst of the crack epidemic (the most violent years in New York's modern history), he secured the money to hire 6,000 additional patrol officers. ${ }^{131}$ Those officers helped Dinkins's successor Rudy Giuliani and his police commissioner William Bratton as they developed Kelling and Wilson's broken windows theory into a strategic blueprint for crime control, implemented through the CompStat system. Adopting a more aggressive approach to select low-level offenses such as marijuana possession in "high-crime" neighborhoods in part as a mechanism for fingerprinting and checking for outstanding warrants, Giuliani and Bratton extended the racial and class logics of street-level drug policing to encompass the city as a whole. ${ }^{132}$

By the early twenty-first century, the open-air drug markets of the 1980s had largely disappeared, and New York's crime rate had begun a remarkable decline. ${ }^{133}$ New York City and New York State revisited the punitive approach to drug policy, reforming the Rockefeller Laws in 2009, removing mandatory minimums, and creating opportunities for diversion to treatment programs. Yet even as drug felony convictions fell, the NYPD continued Bratton's

\footnotetext{
${ }^{129}$ See Commission to Investigate Allegations of Police Corruption ... [Milton Mollen, chair], Commission Report (New York, 1994).

${ }^{130}$ Vitale, City of Disorder.

131 "Dinkins Speech: Retaking the City," NYT, Aug. 23, 1989, B4; Chris McNickle, The Power of the Mayor: David Dinkins, 1990-1993 (New Brunswick, NJ, 2013), 215-7. See also Wilbur Rich, David Dinkins and New York City Politics: Race, Images, and the Media (Albany, NY, 2007), ch. 7.

${ }^{132}$ Vitale, City of Disorder, 43-5, 116-7; Chronopoulos, "The Making of the Orderly City."

${ }^{133}$ The causes of the crime drop are still being fiercely debated. For New York, see Andrew Karmen, New York Murder Mystery: The True Story Behind the Crime Crash of the 1990s (New York, 2000); Franklin Zimring, The City that Became Safe: New York's Lessons for Urban Crime and Its Control (New York, 2012); and Patrick Sharkey, Uneasy Peace: The Great Crime Decline, the Renewal of City Life, and the Next War on Violence (New York, 2018).
} 
use of pretextual misdemeanor arrests and stop-and-frisk searches, sending thousands of lowlevel users and sellers, not to prison, but into jails and lower courts. ${ }^{134}$ In the last decade, the NYPD has cut back on enforcement toward some small-scale drug offenses (particularly marijuana possession), though broken-windows policing remains the department's basic strategy.

This essay has recounted the story of one dimension of a historical phenomenon-mass incarceration-that is now widely recognized as racist and classist. The particular process detailed here-the rebirth of street-level drug policing - was racist and classist, too: people at the bottom of the urban hierarchy, the overwhelming majority of whom were low-income people of color, paid a high price for efforts primarily designed to benefit more affluent New Yorkers. ${ }^{135}$ Yet this history also has a tragic dimension, which underscores the deeply embedded nature of inequality in contemporary American cities. ${ }^{136}$ Most people in all parts of the city preferred to live without the presence of street-level drug markets and the violence that inevitably surrounded them; most New Yorkers wanted easier access to public space, and many people in poorer communities believed drug markets comprised an obstacle to their efforts to improve their own neighborhoods. For these reasons, it is not surprising that many community activists supported stronger street-level drug enforcement-indeed, they often demanded that the city commit policing resources to areas that were not top priorities for the Koch administration or the NYPD, even as they argued that a real solution demanded greater community investment, antipoverty and employment programs, improved health care, and better schools and housing. Yet not only did street-level drug policing in the context of racial injustice throughout the criminal justice system exact terrible costs on individuals, families, and communities, but it also emerged less as a complement than as a competitor-both in terms of access to resources and in how the tasks and techniques of governance in the city were framed-to the more fundamental social policy approaches these community activists preferred. ${ }^{137}$ This bitter irony is indicative of the obstacles to progressive reform in a city where racial inequality and exclusion are so deeply entrenched; and perhaps it helps us to better grasp the forms of power that have allowed policing to remain so central to social and economic governance in the most progressive and cosmopolitan American communities.

Mason B. Williams is assistant professor of leadership studies and political science at Williams College and the 2020-2021 Andrew W. Mellon Foundation fellow at the New York Public Library's Dorothy and Lewis B. Cullman Center for Scholars and Writers. He is the author of City of Ambition: FDR, La Guardia, and the Making of Modern New York (Norton, 2013). With Brent Cebul and Lily Geismer, he co-edited Shaped by the State: Toward a New Political History of the Twentieth Century (Chicago, 2019), and with David Greenberg and Moshik Temkin, he co-edited Alan Brinkley: A Life in History (New York, 2018).

\footnotetext{
${ }^{134}$ Issa Kohler-Hausmann, Misdemeanorland: Criminal Courts and Social Control in an Age of Broken Windows Policing (Princeton, NJ, 2018).

${ }^{135}$ An extensive and still growing literature examines the racialization of crime in twentieth-century urban America. Two especially important works are Khalil Gibran Muhammad, The Condemnation of Blackness: Race, Crime, and the Making of Modern Urban America (Cambridge, MA, 2011); and Hinton, From the War on Poverty to the War on Crime. See also Julilly Kohler-Hausmann's account of the construction of "pusher/sellers" as "anti-citizens"- people whose non-normative behavior, whose ostensible disregard for the effects of their conduct upon the community, merited the forfeiture of their citizenship rights. Kohler-Hausmann, “The Attila the Hun Law,"' 81.

${ }^{136}$ See James Forman, Jr., Locking Up Our Own: Crime and Punishment in Black America (New York, 2017).

${ }^{137}$ See Murch, "Crack in Los Angeles," 163, on how the local state's strategy of governing through crime "hindered political opposition to the drug war by African Americans who were desperately seeking solutions to the public health and social crises facing their neighborhoods."
} 